\title{
Molecular Diagnostic Techniques
}

\section{Review}

\section{Miniaturized Electrophoresis: An Evolving Role in Laboratory Medicine}

BioTechniques 31:1332-1353 (December 2001)

\author{
Lian Ji Jin, Jerome Ferrance, \\ and James P. Landers ${ }^{1}$ \\ University of Virginia and \\ ${ }^{1}$ University of Virginia Health \\ Science Center, Charlottesville, \\ VA, USA
}

\section{INTRODUCTION}

In the early 1990s, miniaturized electrophoresis in the form of capillary electrophoresis (CE) took root as a separation technique that was viewed as an alternative analytical tool to slab-gel electrophoresis (SGE) and HPLC. In particular, $\mathrm{CE}$ was found to possess unique separation capabilities for pharmaceutical, environmental, forensic, and clinical diagnostic analysis. In the latter part of the 1990s, CE has been viewed in a new light, one that has cast its microfabricated counterpart, microchip electrophoresis, in a new and exciting role applied to the same diverse spectrum of applications and more. This article updates recent progress in $\mathrm{CE}$ and microchip electrophoresis, focusing on the area of clinical diagnostic analysis. While the literature covered here is by no means comprehensive, we hope that the sam pling of the pertinent literature provides the reader with a flavor for the current state-of-the-art.

(CE) for supplanting conventional methods in the clinical laboratory led to intense interest in this analytical tool a decade ago. Since then, a number of clinical applications have been defined along with those that have impacted the pharmaceutical, environmental, and forensic arenas. Concurrent with the development of CE applications was the emergence of electrophoresis in the microchip format. The main attraction of this platform, the ability to execute high-resolution separations in a few hundred seconds, was not its only attribute. The capability for parallel processing of separations was complemented by the potential for integrating sample preparation into the same device. This Review highlights recent progress towards CE and microchip electrophoresis as clinical diagnostic tools, with literature coverage from 1996 to 2000. electric focusing (CIEF), and SDS-capillary gel electrophoresis (SDS-CGE) are more commonly used than other modes with clinical applications. CZE is particularly useful for separating small, charged molecules based on differences in their electrophoretic mobilities. Since electrophoresis can be carried out in free solution (no sieving matrix), this mode is simple and easy to perform. MEKC is a mode developed to separate neutral analytes that would otherwise co-migrate with the electroosmotic flow (EOF). Detergents, utilized as micelle formers, are added into the separation buffer and allow neutral analytes to partition between the free solution and micellar phase, which is charged. The resulting complexation imparts charge to the analytes, which are then separated based on their relative affinities for the micellar phase. CIEF simply extends standard tube or slab-gel IEF to capillaries and is primarily used for separating proteins and peptides based on the isoelectric points. SDS-CGE, as inferred by the name, is a capillary version of SDS-PAGE and is useful for the separation of proteins based on size. As a result of the difficulties with forming a uniform gel matrix in narrow bore capillaries, the more popular form of this mode is using a non-gel sieving matrix, such as polyethylene oxide (PEO) and hydroxyethyl cellulose (HEC), which are gellike but easily replaced after each run. A comprehensive overview of the fundamentals of CE can be obtained in References 55 and 59.

Interest in applying $\mathrm{CE}$ to clinical diagnostic analysis was initiated more than a decade ago. Since then, extensive investigations have examined the capability of $\mathrm{CE}$ for executing routine clinical diagnostic protocols previously 
performed either by SGE or HPLC. After a decade or so, what have emerged are four general application areas: protein analysis (serum, cerebrospinal fluid, and urine), ion analysis, drug screening, and molecular diagnostics (DNA analysis) $(87,95)$, in which CE can impact the speed and efficiency of routine clinical analyses.

\section{Protein Analysis in Serum}

Detection of protein abnormalities in serum was among the first clinical CE applications to undergo extensive validation. Since proteins absorb in the UV part of the spectrum, CE with UV detection is predominant in protein analyses. Unless specified otherwise, all the work discussed herein was performed with UV detection. The introduction of the Paragon CZE ${ }^{\circledR} 2000$ (Beckman Coulter, Fullerton, CA, USA) represents the first CE instrument to be approved by the Food and Drug Administration for serum protein electrophoresis (SPE) in a fully automated format. Using low-resolution $\mathrm{CE}$, serum proteins are resolved into five discrete zones - the five-zone pattern is comprised of the albumin, $\alpha_{1}$-globulin, $\alpha_{2}$-globulin, $\beta$-globulin, and $\gamma$-globulin regions. Variation in the content of one or more of these five major fractions, mainly in the $\beta$ and $\gamma$ regions, is correlated with certain disease states. Com parisons of CZE, using either conventional CZE instrumentation or the Paragon CZE 2000, with the two classical manual methods, agarose gel electrophoresis (AGE) and cellulose acetate electrophoresis (CAE), have been reported in the literature for a number of these disease states.

Bossuyt et al. (10) analyzed serum from patients with inter-alia inflammation, nephrotic syndrome, or polyclonal gammopathy and showed that the electrophoretic pattern and clinical information obtained by CE were comparable to AGE or CAE. The abundance of each fraction had poor linear correlation with AGE, but abundances were well correlated with CAE values. Though the CZE method gave higher reference intervals, the results indicate that $\mathrm{CE}$ is a reliable, faster, automated alternative to AGE and CAE. Petrini et al. (74) furthered these studies, com paring reference values obtained with the Paragon CZE 2000 and CAE densitometry, analyzing 1000 random normal and pathological serum samples. The two sets of reference values were in good agreement with each other and with reference values previously reported for CZE systems. Comparisons of SPE by high-resolution agarose gel electrophoresis (HRAGE) and CZE systems other than the Paragon CZE 2000 have also been performed (40, 104). The BioFocus 2000 (Bio-Rad Laboratories, Hercules, CA, USA), ABI 270 HT (Applied Biosystems, Foster City, CA, USA), and Beckman P/ACE 5500 CE systems (Beckman Coulter) all produced results comparable to those obtained with HRAGE.

The Paragon CZE 2000 is designed not only for routine SPE but also for monoclonal component (MC) typing (7). For MC typing, CE is performed on the supernatant of a patient serum after reaction with beads coated with an immunospecific reagent $(\operatorname{IgG}, \operatorname{Ig} A, \operatorname{IgM}$, $\kappa$, or $\lambda$ ). This process, termed immunosubtraction (IS), removes specific components from the serum to identify peaks. In a study involving three laboratories, evaluation of the Paragon CZE 2000 for SPE and MC typing found that CZE and CAE gave comparable results on 794 samples (7). Immunosubtraction on 403 of the samples was found to be adequate for the identification of the monoclonal type in all sam ples. These results are consistent with another clinical study involving 240 patients (46), which compared SPE analysis by AGE and the Paragon CZE 2000 for the detection of dysproteinemia and paraproteinemia. Concordance studies showed 96\% agreement between AGE and CZE involving dysproteinemia, while paraprotein classification, which compared CZE-IS to agarose im munofixation (IF), showed an agreement of $100 \%$.

While these studies suggest that the Paragon CZE 2000 is an efficient, highly reproducible system for both SPE and MC typing, there are defining differences. Comparison of the Paragon CZE 2000-IS with AGE-IF for the detection and identification of monoclonal gammopathies has been carried out (60). In this study, 617 serum samples were first analyzed with CZE and AGE to determine sensitivity and specificity in detecting IF-confirmed monoclonal gammopathies. Both CZE and AGE detected all monoclonal spikes. However, immunosubtraction was only capable of correctly immunotyping 60\%-75\% of monoclonal gammopathies confirmed by IF in a follow-up study. This suggests that CZE should only be used to immunotype discrete and prominent monoclonal proteins, and any IS pattern that does not appear definitive should be further confirmed by IF.

In contrast, Clark et al. (15) demonstrated the ability of CZE-IS to analyze gammopathies in serum samples that were problematic by AGE-IF (Figure 1). Serum profile abnormalities, difficult to detect/interpret by AGE-IF, were subdivided into four categories: samples with $(i)$ a polyclonal increase in immunoglobulin, (ii) point of application artifacts, (iii) abnormalities in the beta region, and (iv) free light chains. $\mathrm{CE}$ was found to be superior to AGE for evaluating samples characterized by three of these abnormalities. The exception was serum that contained free light chains but did not present any apparent abnormality in the serum profile. Katzmann et al. (49) also performed a prospective study for immunotyping of monoclonal proteins with serum protein samples from 1518 patients. The data obtained with Paragon CZE 2000IS was compared to AGE-IF. The CZE had a sensitivity and specificity of $95 \%$ and $99 \%$, while AGE reached $91 \%$ and $99 \%$. Thus, the IS method was more sensitive, technically simpler, and more automated than IF for immunotyping of monoclonal proteins in serum. Henskens et al. (31) performed a parallel study comparing CZE-IS with AGEIF for the detection and identification of monoclonal gammopathies. They concluded that CZE-IS could be a useful method for the detection of paraproteins and a good alternative to AGE-IF.

Transferrin (Tf), hemoglobin ( $\mathrm{Hb}$ ), and lipoprotein are other serum proteins of clinical interest that have been investigated using CE. Tf, a serum protein known to transport iron, exists in different sialoforms with varying numbers of sialic acids attached to carbohydrate moieties on the protein. Carbohydrate-deficient Tf (CDT), lacking sialic acid and/or carbohydrate groups, can 


\section{Molecular Diagnostic Techniques}

be an indicator of liver damage, as inferred from its elevated concentration in patients prone to chronic alcohol abuse. There is no current standardized method available for CDT analysis. Recently, isotransferrin collected from anion-exchange fractionation was analyzed by isoelectric focusing (2). A drawback inherent to the anion-exchange sample pretreatment step is the incomplete and variable recovery of the different CDT-isotransferrins in the column effluxes and the failure to detect genetic $\mathrm{Tf}$ variants. Thus, this method caused false-positive (Tf-D) or false-negative (Tf-B) results. Using CE, however, CDT profiles were obtained that could be useful for CDT-related disease diagnosis $(25,71,75,93,98)$. Direct $\mathrm{CE}$ analysis of serum to detect $\mathrm{Tf}$ sialoforms was achieved in less than 30 min either with hydroxyethyl cellulose/borate buffer (98) (Figure 2) or with borate buffer/diaminobutane (25). With the hydroxyethyl cellulose/borate buffer, the CDT profiles from nonalcoholic and alcoholic patient sera are readily distinguishable (98).

$\mathrm{Hb}$ and a number of $\mathrm{Hb}$ variants are analyzed for clinical diagnosis of con-
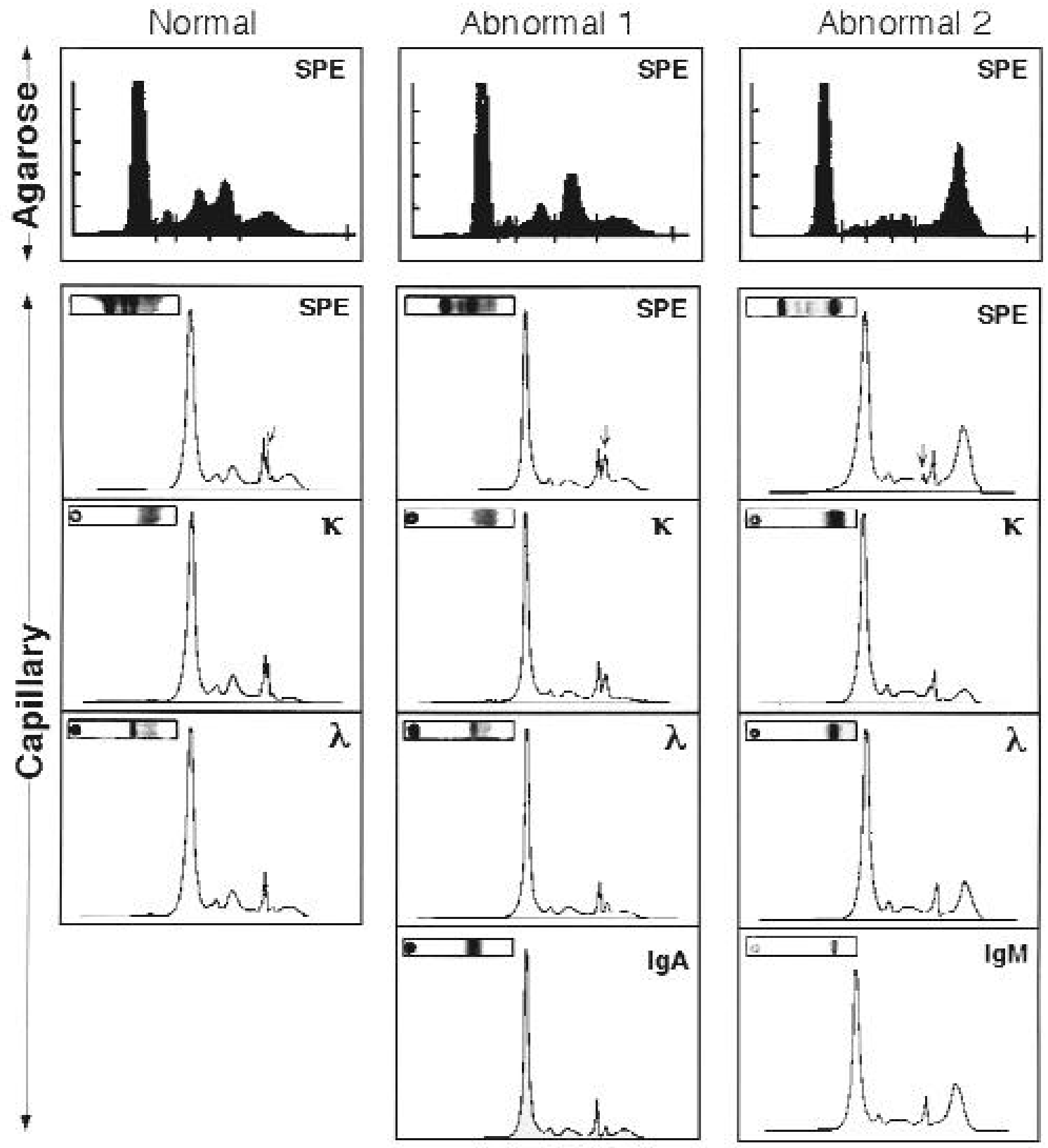

Figure 1. Sera containing abnormalities in the $\beta$ region not detected by AGE. Normal, $\lambda$ free light chain seen as an extra $\beta$ peak by CZE. Abnormal 1 , IgA $\lambda$ monoclonal protein seen as a broad $\beta 2$ peak on CZE. Abnormal 2, very small $\operatorname{IgM} \lambda$ monoclonal protein seen as an extra $\beta$ peak. 
genital hemoglobinopathy and thalassemia disorders (27). CIEF has been shown to be an effective method, with the diagnostic sensitivity and specificity for detecting $\mathrm{Hb}$ and its variants based on alterations in their isoelectric point $(\mathrm{p} I)(27,28,29,44)$. Hempe and Craver (27) have done much of the pioneering work in this area. They performed CIEF of hemolysates prepared from blood samples using a control hemolysate as an external standard to estimate the $\mathrm{p} I \mathrm{~s}$ of $\mathrm{Hb}$ variants in unknown samples. Four common abnormal $\mathrm{Hb}$ variants $(\mathrm{C}, \mathrm{S}, \mathrm{D}$, and $\mathrm{G})$ can be confidently identified by CIEF in a single analysis, whereas $\mathrm{Hb} \mathrm{E}, \mathrm{C}$ Harlem, and $\mathrm{O}-\mathrm{Arab}$ variants were not differentiated because of their similar $\mathrm{p} I$ values. In this study, several thousand patient samples were analyzed by CIEF, confirming that $\mathrm{p} I$ is a reproducible, objective, and specific criterion for identification of these four com mon $\mathrm{Hb}$ variants. Hempe et al. (28) further examined CIEF for the primary evaluation of hemoglobinopathies and thalassemias. CIEF again provided a high-efficiency separation, but they also found precise quantitation of com mon $\mathrm{Hb}$ variants (including $\mathrm{HbA}_{2}$, $\mathrm{HbS}, \mathrm{HbF}, \mathrm{HbA}$, and $\mathrm{HbA}_{\mathrm{lc}}$ ) over a wide range of concentrations, without adjunct analyses. Jenkins et al. (44) carried out $\mathrm{CIEF}$ on Helena Titan III-H AFSC Hemo Control (containing $\mathrm{HbC}$, $\mathrm{HbS}, \mathrm{HbF}, \mathrm{HbA}$, and $\mathrm{HbA}_{\mathrm{lc}}$ ) and hemolyzed red cells using a one-step salt mobilization to achieve isoelectric focusing of $\mathrm{Hb}$ variants in capillaries. The $\mathrm{p} I$ markers were used to confirm the $\mathrm{p} I \mathrm{~s}$ of $\mathrm{Hb}$ variants in this study. They concluded that CIEF had greater resolution than $\mathrm{CZE}$ and was faster than gel IEF; thus, CIEF should become increasingly popular in clinical laboratory analyses.

Glycosylated $\mathrm{Hb}\left(\mathrm{HbA}_{\mathrm{lc}}\right)$, arising from the post-translational modification of $\mathrm{HbA}$, is the major glycohemoglobin species in human blood (16). Its serum concentration is an excellent tool for long-term monitoring of the glycemic state of diabetic patients, but the variation in the levels of $\mathrm{HbA}_{\mathrm{c}}$ is small between the patients at low and high risk. A number of methods are currently used to monitor the variations, but none is internationally ac- cepted (52). Conti et al. (16) conducted quantitative analysis of $\mathrm{HbA}_{\mathrm{Ic}}$ in human adult blood by CIEF and showed that CIEF is in agreement $( \pm 6 \%)$ with standard zone electrophoresis using the Helena REP Glyco Gel slab system, one of the standard methods in clinical chemistry. CE separation of peptides followed by electrospray ionizationmass spectrometry (ESI-MS) was also established as a candidate reference method for $\mathrm{HbA}_{\mathrm{Ic}}$ (52). With these separation techniques, it has been possible to overcome the insufficient resolution of currently used protein separation systems for $\mathrm{HbA}_{1 \mathrm{c}}$. Doelman et al. (20) also evaluated a $\mathrm{CE}$ method for $\mathrm{HbA}_{1 \mathrm{c}}$ determination, showing no interference from other $\mathrm{Hb}$ variants $(\mathrm{HbF}, \mathrm{HbS}$, and $\mathrm{HbC})$. They concluded that $\mathrm{CE}$ was a valuable analytical tool for $\mathrm{HbA}_{1 \mathrm{c}}$ determination in the clinical laboratory.

$\mathrm{Hb} \mathrm{A}_{2}$, another hemoglobin variant, comprises only $1.5 \%-3 \%$ of the total $\mathrm{Hb}$ in erythrocytes. Elevated levels of $\mathrm{Hb}_{2}$ are used to aid in the diagnosis of $\beta$-thalassemia and other clinical disorders (88). While $\mathrm{HbA}_{2}$ can be separated effectively from other components with AGE, the densitometric scans are not sensitive enough to detect small changes in the quantity of $\mathrm{HbA}_{2}$. Microcolumn chromatography and HPLC are also used, but they are either complicated or time consuming. Shihabi et al. (88) compared CZE with the microcolumn method for detection of $\mathrm{HbA}_{2}$ in a normal patient, one with $\beta$-thalassemia and one with the hemoglobin $\mathrm{S}$ trait. CZE performed better with elevated $\mathrm{HbA}_{2}$ and as well with normal and decreased levels as the microcolumn method. Cotton et al. (18) also evaluated a CZE kit for routine determination of $\mathrm{HbA}_{2}$ and $\mathrm{HbF}$. They found that the method correlated well with cation-exchange HPLC for $\mathrm{HbA}_{2}$ and $\mathrm{HbF}$ and with anion-exchange microcolumn chromatography for $\mathrm{HbA}_{2}$. Jenkins et al. (42) also developed a CZE method to identify the $\mathrm{Hb}$ variants but found that the method, though suitable for quantitation of $\mathrm{HbA}$, was unsuitable for quantitation of $\mathrm{HbF}$.

Coupling $\mathrm{CE}$ with mass spectrometry (MS) detection for determination of $\mathrm{Hb}$ variants has also been documented $(13,58)$. Cao and Moini (13) reported the separation and detection of $\alpha$ - and $\beta$-chains of $\mathrm{Hb}$ from a single intact red blood cell using CE/ESI time-of-flight (TOF) MS. The multiply protonated and sodiated $\alpha$ - and $\beta$-chains of $\mathrm{Hb}$ were identifiable from the mass spectra. Li et al. (58) used CE/ESI ion trap (IT)/reflectron (re) TOF/MS to develop a rapid and sensitive method for detecting $\mathrm{Hb}$ variants in trypsin-digested $\beta$ chains. The $\alpha$ - and $\beta$-chains were first separated, and the $\beta$-chains were then digested and analyzed by CE/ESIIT/reTOF/MS. By comparing the total ion electropherograms and the mass spectra of mutant and normal Hbs, the mutation site could be determined.

One further study on the clinical use of $\mathrm{CE}$ for evaluating hemoglobin reports on the detection of carbon monoxide ( $\mathrm{CO}$ ) binding to the heme portion of the $\mathrm{Hb}$ molecule. The determination of CO-heme content is important in quantifying fatal and nonfatal levels of $\mathrm{CO}$ in blood samples of accident victims. Durkin et al. (21) successfully analyzed heme and CO-heme concentrations using $\mathrm{CE}$ in samples isolated from the blood.

Lipoprotein and apolipoprotein analysis of serum is important for detecting plasma lipoprotein transport system disorders, major factors contributing to the high prevalence of coronary artery disease in the Western population (91). Schlenck et al. (82) investigated the capillary isotachophoresis (CITP) method with laser-induced fluorescence (LIF) detection to analyze 35 ceramide-labeled normolipidemic serum lipoproteins. This automated method proved to be rapid (6 $\mathrm{min})$ and reproducible ( $\mathrm{CV}<7 \%)$ with separation of the main lipoprotein groups, highdensity lipoprotein (HDL), very lowdensity lipoprotein (VLDL), and lowdensity lipoprotein (LDL). Stocks and Miller (91) reviewed lipoprotein and apolipoprotein separations by various CE modes including SDS-CGE, CZE, CIEF, and CITP. While SDS-CGE can resolve apolipoprotein (apo) A-I, apo A-II, apo E, and apo A-IV in isolated HDLs, CZE has been shown to be effective for resolving apo A-I isoforms, pro-apo A-I, and deamidated apo A-I, as well as HDL apolipoproteins. CIEF proved useful for the separation of human apo A-I isoforms with polysiloxane-coated capillaries, whereas CITP 


\section{Molecular Diagnostic Techniques}

could resolve plasma lipoproteins into four HDL subfractions and two LDL subfractions.

\section{Protein Analysis in Urine}

Urine proteins originate from serum proteins; therefore, they have similar patterns and distribution (23). The principal reason for urine protein analysis is to identify the presence of Bence Jones protein, which is important in the assessment of patients with multiple myeloma, a malignant tumor in the bone marrow found in greater than $3 \%$ of the population aged over 70 years $(38,39,41)$. Urine protein electrophoresis can also be used to distinguish glomerular from tubular proteinuria, with albumin being the main protein marker for the glomerular pattern, while $\beta_{2}$-microglobulin, $\alpha_{1}$-microglobulin, and retinol binding protein are typical with the tubular pattern (39). Urine protein analysis with and without urine cleanup has been studied by $\mathrm{CE}$ and compared to the currently used method of HRAGE $(23,39)$. Urine sam ples pretreated either with adsorptive filtration combined with a wash step or cold ethanol precipitation followed by $\mathrm{CE}$ yielded results comparable to the AGE. Overall, CE was found to be faster and more effective than AGE using either clean-up method (39). Unconcentrated human urine proteins were also analyzed by $\mathrm{CE}$ and gave results comparable to those obtained when the concentrated urine was diluted. Bence Jones protein and other clinical patterns, such as glomerular proteinuria, the presence of intact imunoglobulin, and Tamm Horsfall protein could be identified in the unconcentrated samples (39). In general, the CE separation of unconcentrated urine was concluded to be a sensitive, specific, and cost-effective method for urine protein analysis.

\section{Protein Analysis in Cerebrospinal Fluid}

The evaluation of human cerebrospinal fluid (CSF) proteins is of im portance in examining disorders of the central nervous system (CNS). Current methodologies involve HRAGE and nondenaturing micro 2-D PAGE

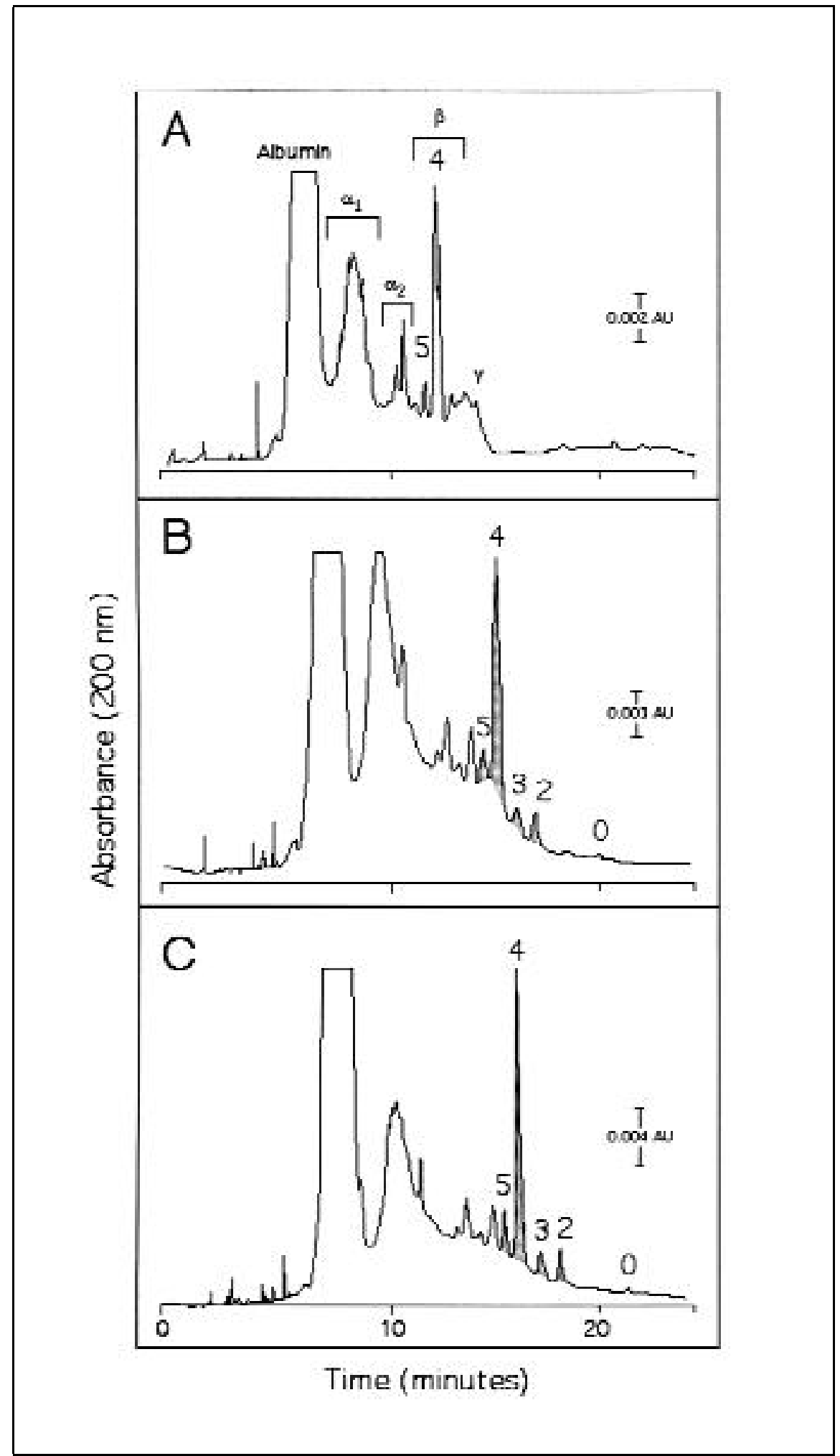

Figure 2. Capillary electrophoretic detection of Tf sialoforms following direct injection of serum. (A) Untreated alcoholic patient serum. Separation conditions: capillary, $50 \mu \mathrm{m} \times 27 \mathrm{~cm}$ FC-coated containing $100 \mathrm{mM}$ borate buffer, $\mathrm{pH} 8.5$, with $0.5 \% \mathrm{HEC}$ at $15 \mathrm{kV}$; temperature, $20^{\circ} \mathrm{C}$; pressure injection at $0.5 \mathrm{psi}$ for $5 \mathrm{~s}$; detection at $200 \mathrm{~nm}$. (B) Serum diluted 1:20 in water. (C) Serum diluted 1:20 in $500 \mu \mathrm{M}$ ferric citrate. Separation conditions of (B) and (C) are the same as for (A), except for capillary length (37 $\mathrm{cm})$ and pressure injection $(40 \mathrm{~s})$. The Tf sialoforms are numerically identified to indicate the number of terminal sialic acid residues (e.g., $4=$ tetrasialo-Tf). 
$(63,81)$. CE separation of CSF proteins has been investigated using CIEF, CZE, and SDS-CGE modes $(32,33,63,81)$. Manabe et al. (63) established CIEF for CSF protein analysis, resolving 70 protein peaks and shoulders within $60 \mathrm{~min}$ with the sample dialyzed before analysis. The results suggested that CIEF would be useful as a survey method to detect specific proteins related to CNS disorders. Sanders et al. (81) developed CZE as an alternative of HRAGE to detect the presence of oligoclonal bands in CSF, a diagnostic indicator of multiple sclerosis. Borate buffer augmented with polyethylene glycol provided enhanced resolution of oligoclonal bands in a study of 24 patient samples. They also showed that zwitterionic additives such as O-phosphorylethanolamine may further improve the resolution and allow oligoclonal banding information to be obtained directly from CSF without pre-concentration. Hiraoka et al. (33) investigated SDS-CGE, which requires far less sample and shorter analysis time than conventional SDS-
PAGE, for the analysis of CSF proteins of low molecular weights. Simultaneous detection of $\beta_{2}$-microglobulin $(\beta \mathrm{MG}), \gamma$-trace protein, myelin basic protein, $\beta$-trace protein ( $\beta \mathrm{TP}$ ), and $\alpha(1)$-acid glycoprotein was obtained. This study showed that the levels of $\beta \mathrm{TP}$ were increased nonspecifically in a variety of organic CNS diseases, especially in those that cause severe physical damage to brain tissue.

\section{CE of Small Molecules}

The direct applicability of CE to the separation of small molecules, including neutral or uncharged analytes, has allowed the implementation of this method in therapeutic drug monitoring (TDM). TDM is required for assisting in accurate dosing in select disease therapies and diagnoses. Some examples of validated CE-based drug assays included deoxyuridine in plasma and urine (72), albendazole in plasma (76), purines in urine (100), and acetaminophen along with some other drugs

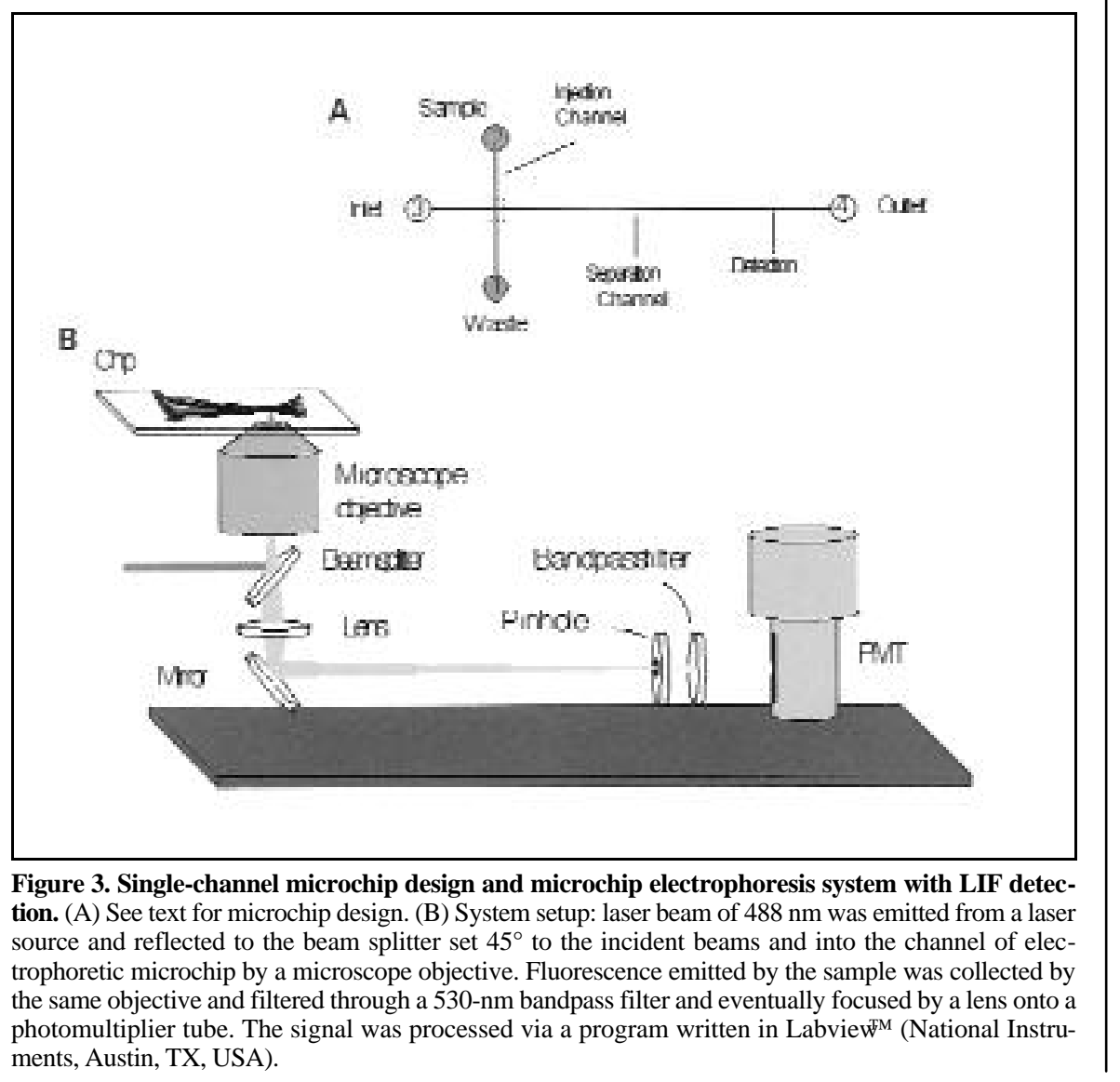




\section{Molecular Diagnostic Techniques}

in plasma (54). Drug monitoring in forensic applications has also been demonstrated using the $\mathrm{CE}$ technique. Recent progress on these topics was comprehensively reviewed in References 30, 90, and 95.

$\mathrm{CE}$ has also been investigated as a routine tool for evaluating kidney function via the measurement of the glomerular filtration rate (GFR) $(6,35,43,80$, 105). Renal function has traditionally been determined by the infusion of insulin and, more recently, by ${ }^{125}$ I-labeled iothalamate injection. With radioactive exposure, limited shelf life, and disposal of radioactive materials presenting potential hazards and increased cost, different nonradioactive markers (e.g., iothalamate and iohexol) have been evaluated to replace the [I- $\left.{ }^{125}\right]$ iothalamate. Excellent correlations between CE-determined GFR values using these new markers and values obtained by traditional GFR methods were observed. This provides a cost-effective alternative that avoids the problems associated with radioactive isotopes.

\section{Molecular Diagnostics}

PCR, a method for amplification of specific DNA targets of interest in biological specimens, is a key component of molecular (DNA) diagnostics. The automated capabilities of CE with LIF detection has been shown to be very powerful for clinical analysis of PCR products $(73,84)$. In particular, CE has proven valuable in detecting mutations involving human tumor suppressor genes, oncogenes, and disease-causing genes $(49,77)$, highlighting the importance of PCR-mediated mutation detection as a seminal tool in clinical diagnostics. One well-established method for detecting mutations is single-stranded conformational polymorphism (SSCP), where analysis is based on differences in the ssDNA conformation when aberrations, even as subtle as a single point mutation, exist. This conformation change is detected as an electrophoretic mobility shift between the wild-type and mutant alleles. Using CESSCP for mutation detection has been active in recent years, with a number of the reports briefed in the following text. The advantage associated with using commercial CE instruments is that gel loading, sample loading, separation, and detection can be fully automated. However, sample preparation remains problematic for automation so far.

Liu et al. (62) developed a CE-LIF method for single point mutation detection in codon 12 of the human K-ras gene. The combination of a fluorescently labeled reverse primer and an unlabeled forward primer was used for PCR amplification of a selected 50-bp sequence, and direct injection of $\mathrm{NaOH}$ was optimized for online denaturation. Through comparison with control samples, mutant samples could be identified with an electrophoretic analysis time of less than 20 min. Nishimura and Tsuhako (69) achieved sensitive and reproducible CE-LIF analysis of the N-ras oncogene, known to possess a point mutation at codon 61 in neuroblastomas. Using this method, wild-type and mutant ssDNA fragments were resolved within 7 min. Tian et al. (97) demonstrated the use of CE-LIF SSCP analysis for screening three common mutations in BRCA1 and BRCA2, two breast cancer susceptibility genes. Flu- orescent dye-labeled forward and reverse primers were used to amplify DNA fragments of 258, 296, and 201 bp for the detection of the $185 \mathrm{del} A G$, 5382insC, and 6174delT mutations, respectively. Using the appropriate polymer matrix (HEC-based), CE-based SSCP profiles for each mutation could be obtained in less than $10 \mathrm{~min}$. Arakawa et al. (1) studied mutation detection in the $\operatorname{divE} 42$ gene and N-ras gene by CE-SSCP. The results also indicated that two ssDNA that differ in only one nucleotide can be separated by $\mathrm{CE}$ within minutes. All mutations tested in this study were distinguished.

Ren et al. (78) investigated the effects of temperature and $\mathrm{pH}$ for CESSCP analysis with nine different mutations of the factor $\mathrm{V}$, cystathionine $\beta$-synthase, and methylenetetrahydrofolate reductase genes. It was found that low temperature, in general, increased the number of detectable single-strand conformations and thereby enhanced the sensitivity of the analysis. The $\mathrm{pH}$ effects of the separation matrix varied for different DNA fragments. Seven of nine single-point mutations were detected at $\mathrm{pH} 8.3$, while the CBS T833C mutation discrimination required $\mathrm{pH}$ values of 6.4 and 9.0. One mutation (CBS G797A) could not be detected at any $\mathrm{pH}$, emphasizing the importance of the separation matrix $\mathrm{pH}$ and that no universal set of conditions exist with SSCP analysis.

Hereditary hemochromatosis (HHC) represents an autosomal recessive disease in which increased iron absorption causes iron overload and irreversible tissue damage. Two point mutations in the $H F E$ gene on chromosome $6 \mathrm{p}$ were determined to be associated with the HHC disease. Bosserhoff et al. (9) developed a CE-SSCP method that allowed the detection of homozygote or heterozygote point mutations with a single PCR, omitting the need for further analysis by restriction digestion. The CE-SSCP results from 85 patients with liver disease and/or suspected iron overloads were verified by conventional RFLP analysis. This method proved to be reliable, cost effective, sensitive, and rapid for genotyping $H F E$ mutations. Wenz et al. (102) also reported the CE-SSCP-based detection of two mutations in the HFE gene. In this 


\section{Molecular Diagnostic Techniques}

study, 20 samples were analyzed blind, and all of the genotypes deduced were in concordance with the RFLP results.

Mutation detection on the human tumor suppressor gene p53 has also attracted considerable research efforts using CE-LIF-SSCP. Wenz et al. (103) analyzed 10 blinded samples of p53, correctly identifying six as containing one of the reference mutations, two as the wild-type, and two were identified as non-reference mutations. Atha et al. (3) analyzed five select p53 single-point mutations and all CE-LIF-SSCP-derived data agreed well with the SGE results. Compared with standard SGESSCP, the CE-SSCP method was 10 -fold faster and more automated. Katsuragi et al. (48) also used CE-SSCP to study mutations in the p53 gene. Elec- trophoresis of ssDNA was carried out in $2 \%$ linear polyacrylamide polymer solution with $5 \%$ glycerol. Four tissue specimens from lung tumors were found to have separate mutant alleles in exon 7 of the p53 gene; a 6-bp deletion at codons 247-248, a 1-bp deletion at codon 260, a 1-bp deletion at codon 244, and a GGC to CGC substitution at codon 244. The results of this study showed that CE could be used to perform rapid and automatic SSCP analysis. The current methods used for diagnosis determination in clinical testingvisual inspection and interpretation of patterns on X-ray films and ethidium bromide or silver-stained gels-were replaced by computer interpretation.

Larsen et al. (56) reported CE-LIF$\mathrm{SSCP}$ for robust multiplex analysis and pattern-based identification of point mutations associated with the inherited cardiac disorders, long QT syndrome (LQTS) and hypertrophic cardiomyopathy (HCM). Primers labeled with FAM, HEX, or TET were used to obtain PCR products of each strands, and an internal standard GS500 labeled with TAMRA was mixed into each tube with three samples for simultaneous analysis by CE-LIF. Sensitivity of the method was $100 \%$ with 34 different point mutations with the aid of different temperature electrophoresis from $14^{\circ} \mathrm{C}$ to $45^{\circ} \mathrm{C}$. The PCR fragments covered a large range (166-1223 bp), and the CE method was found to be more sensitive than conventional SSCP analysis in the narrower 100-300-bp DNA fragment range.

CE-LIF-SSCP is not only well suit-

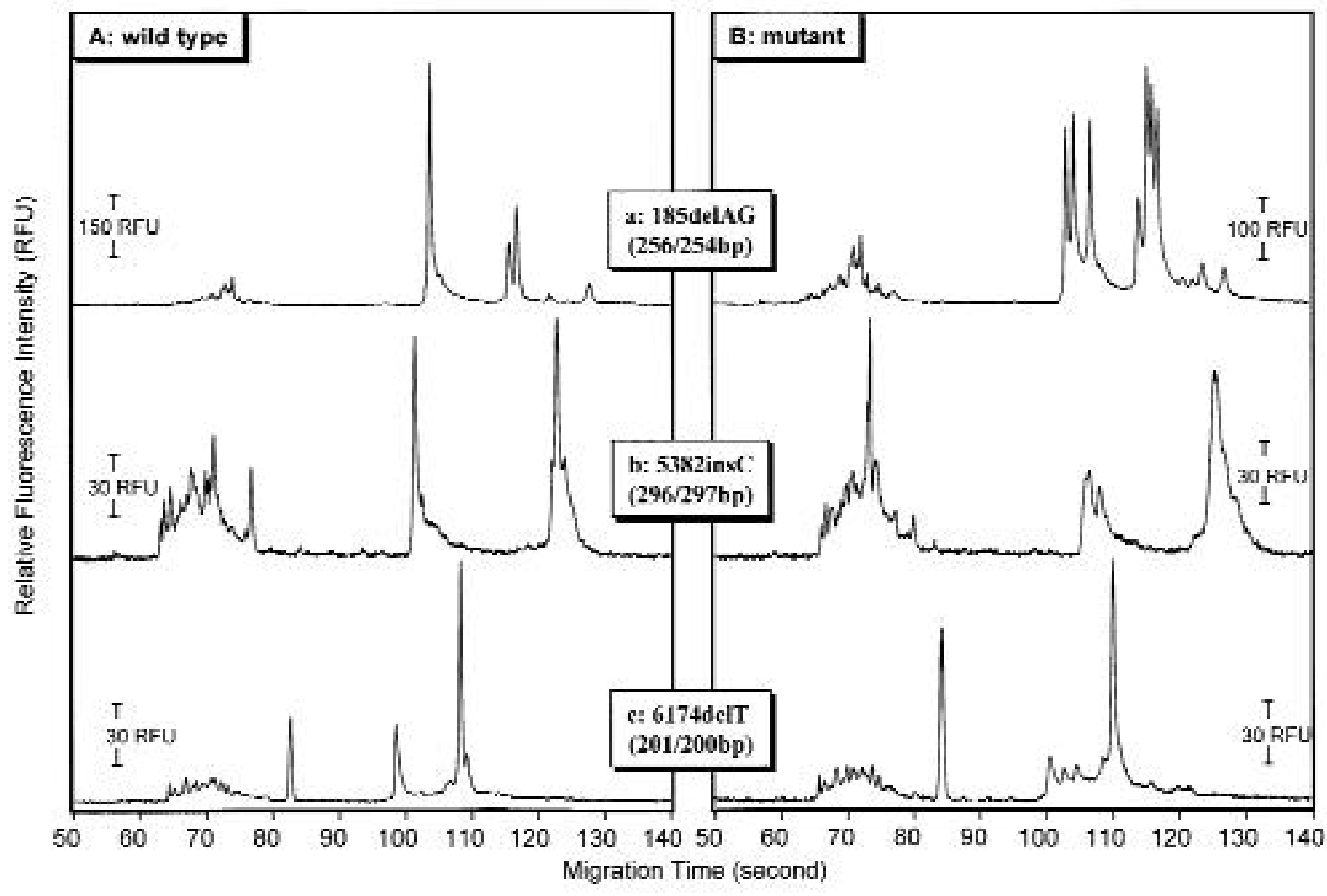

Figure 4. SSCP profiles of wild-type and three mutants (185delAG, 5382insC, and 6174delT) on BRCA1 and BRCA2 genes obtained by microfabricated chip electrophoresis. The sizes of the DNA fragments amplified were 258, 296, and $201 \mathrm{bp}$ for the 185delAG, 5382insC, and 6174delT alleles, respectively. There are obvious differences between the wild-type and the mutant alleles: the wild-type allele has one or three peaks, while the mutant alleles have three to seven peaks in the range of 90-130 s. The channel on the chip was coated with PVP. LIF detection (excitation/emission 488/520 nm) was used. In all cases, $1 \mu \mathrm{L}$ PCR product was mixed with $10 \mu \mathrm{L}$ deionized formamide and $0.5 \mu \mathrm{L} 0.3 \mathrm{M} \mathrm{NaOH}$, heated at $95^{\circ} \mathrm{C}$ for $5 \mathrm{~min}$, and chilled on ice for $5 \mathrm{~min}$ before injection. The denatured PCR product was injected into the channel using the "plug injection" method. The running buffer was $2.5 \%$ HEC containing $10 \%$ glycerol. The separation voltage was $573 \mathrm{~V} / \mathrm{cm}$. 


\section{Molecular Diagnostic Techniques}

ed for the analysis of known mutations but also applied for mutation screening. Inazuka et al. (36) evaluated CE-LIFSSCP as a screening method for mutation detection. Known mutations [i.e., 23 mutations in the gyrA gene of Bacillus subtilis, 5 mutations in exon 7 of human factro IX (hFIX), and 6 mutations in exon 8 of the same gene] were selected as model systems. The appropriate regions in the mutant and reference (wild-type or normal) genomes were PCR amplified, followed by fluorescent labeling of each strand with R110- or R6G-dNTPs (internal standard with TAMRA-dNTPs) in the same tube. The precise calibration of mobilities of normal DNA between runs, which was provided by the multicolor detection capability of the CE system, enabled the sensitive detection of mobility shifts of mutant DNA. Length limit was also significantly increased from less than 300 bp in conventional SSCP to at least 740 bp or even higher with the CE system. Turnaround time with current $\mathrm{CE}$ systems is about $20 \mathrm{~min}$ per sample per instrument including replacement of matrix, sample loading, and separation. Walz et al. (99) performed mutation screening of LDL receptor gene, which consists of 18 exons and more than 350 different mutations that are the cause of a marked elevation of plasma cholesterol and the clinical phenotype of familial hypercholesterolemia. Because of the heterogeneous nature of the mutations spread over the entire LDL receptor gene, all 18 exons had to be studied in a diagnostic approach for which 20 different PCRs were needed to analyze the whole gene. The strategy adopted here was to perform multiplex analysis of different DNA sequences, each strand of which was labeled with different dyes (FAM for forward primers and HEX for reverse primers). To minimize the complexity of the peak pattern, the multiplex analysis was lim ited to the combination of two PCR products. Each abnormal fragment pattern showed high reproducibility in CELIF-SSCP analysis and was characteristic for each mutation; this can be very useful for characterizing newly diagnosed mutations by simply comparing the peak patterns followed by sequence confirmation.

In addition to mutation detection,
CE-SSCP has also been explored for bacterial identification and genotyping applications. Ghozzi et al. (24) utilized CE-SSCP to analyze $16 \mathrm{~S}$ rRNA gene fragments for the rapid identification of Pseudomonas aeruginosa and other gram-negative non-fermenting bacilli isolated from patients with cystic fibrosis $(\mathrm{CF})$. Forward and reverse primers (P11P-P13P) labeled with TET (green) and FAM (blue) fluorescent dyes were used for PCR amplification of target sequences of a 217-bp fragment from $E$. coli 16S rRNA positions 1173-1389. The PCR products were denatured by heating and separated by CE using $4 \%$ polymer and $10 \%$ glycerol. CF clinical isolates (207) were tested and the CESSCP patterns obtained were identical to those for the corresponding reference strains. CE-based SSCP analysis is advantageous in that two strands of DNA could be labeled with different colors; therefore, comparison of same strands from different samples was easy to perform. In addition, CE-SSCP is capable of analyzing a large number of strains with highly reproducible results.

Other than SSCP developed in $\mathrm{CE}$ mode for mutation detection, microsatellite DNA sequences or short tandem repeat (STR) sequences also have been utilized in capillary array electrophoresis (CAE) for genetic disease studies. Medintz et al. (65) showed that loss of heterozygosity ( $\mathrm{LOH}$; specifically loss of microsatellite allele) was easily detected in tumor samples, as was the gain/loss of microsatellite core repeats. Ninety-six separations were obtained parallel in 75 min using a 96 capillary array electrophoresis instrument. Comparison with radioisotope slab-gel-based LOH analysis indicated that the fluorescent technique was able to detect a significantly higher number of LOH samples on 26 sets of renal carcinomas.

Heteroduplex analysis (HDA) in slab-gel format is a popular method in specific point mutation scanning. The advantage over other techniques is that PCR products can be analyzed with little or no further manipulation. Recently, transfer of HDA from the slab-gel format to capillary and microchip systems has also been demonstrated $(37,94,96)$. Jackson et al. (37) reported the HDA screening for hemochromato- sis, a genetic disease in which excessive iron absorption leads to iron overload and tissue damage caused by Cys282Tyr mutation. A heteroduplex generator constructed identical to the PCR product, except for a specified sequence alteration in the vicinity of the mutation, was utilized to form hybridization with PCR product of the gene region containing the mutation. The 100 subjects who were genotyped using HDA (all of which showed clear distinction between individuals who did not carry the mutation) were heterozygous or homozygous for the mutation. HDA results obtained by both silver staining and CE were $100 \%$ concordant with those obtained by restriction digestion of PCR product. Thomas et al. (94) modified the HDA slab-gel format and performed CE-based HDA with a universal heteroduplex generator for the detection of point mutations associated with rifampin resistance in tuberculosis. The universal heteroduplex generator that contained four 3-bp deletions and four 2-bp substitutions com pared with the wild-type $r p o \mathrm{~B}$ sequence was strategically constructed to enhance electrophoretic discrimination of the common mutations encountered in rifampin-resistant Mycobacterium tuberculosis. The CE-based assay performed under optimized conditions, with $0.3 \%$ methyl cellulose as a separation matrix and $1 \mu \mathrm{M}$ YOPRO1 for online LIF, allowed for detection of the presence of $M$. tuberculosis with drastically reduced time when compared to slab-gel (30 min vs. $2.5 \mathrm{~h}$ ). Tian et al. (96) reported an HDA combined with allele-specific PCR (AS-PCR) amplification approach in CE and a microchip format for the rapid detection of known mutations. The general principle of ASPCR for known mutations is that mutation-specific primer is designed to preferentially amplify a mutant allele, which is similar to the PCR primer design in slab-gel AS-PCR. CE-based AS-PCR-HDA showed that homozygous wild-type, homozygous mutant, and heterozygous mutant could be discriminated based on the number of peaks or the profile appearance with analysis times of $10-25 \mathrm{~min}$. It was concluded that the combination of ASPCR with HDA was possible for the rapid and automated detection of spe- 
cific mutations.

Constant denaturant CE (CDCE) also proved to be a useful approach for mutation detection. The constant denaturing condition was maintained by a heating zone surrounding the capillary and without adding chemical denaturant. The separation principle is based on the melting behavior of the dsDNA in a given fragment. At a certain temperature, the fragment establishes rapid equilibrium between completely double-stranded and partially melted conformations. DNA fragments in a partially melted conformation have greatly reduced electrophoretic mobility. When the sequence variants are located in the melting domain, the melting equilibrium is affected and, as a result, so is the electrophoretic mobility of the fragment. This electrophoretic mobility difference is used in CDCE to separate mutant from wild-type allele. Bjørheim et al. (8) evaluated CDCE for the detection of $k R A S$ exon 1 mutations. Among 191 sporadic colon carcinomas samples, 66 (34.6\%) were detected using CDCE. The sequence of the mutant was determined by comparing the electrophoretic pattern to that of known mutations or by mixing the sample with known mutations for re-analysis. The CDCE approach was also compared to temporal temperature gradient electrophoresis and AS-PCR in this report. Khrapko et al. (50) developed a CE hybridization method for the identification of point mutations in mixtures of DNA sequence variants. CDCE was first used to separate sequence variants of sample and standards. The sequence variants of the sample are initially identified based on co-migration with standards and further confirmed by hybridization of the sample variants with the co-migration standards within the capillary. The significance of this method is that it enables direct determination of sequence variants in a mixture, with no need for time-consuming isolation of individual species. Ekstrøm et al. (22) used CDCE to detect lowfrequency point mutations in exon 8 of the TP53 gene, a tumor-suppressor gene commonly mutated in human cancer. Mutant frequency as low as one mutant per 1000 wild-type sequences was found in TP53 gene variants in the area around tumors. CDCE was demonstrated to be able to detect mutant fractions as low as $1 / 1000$ without any prior enrichment for mutant sequences. In addition, different peak patterns for different point mutations were also observed that served as "fingerprint" in the electropherograms for specific mutation identification. Under optimal CDCE conditions and with PCR performed in a capillary air thermal cycler, the sample could be analyzed in about 60 min. The CDCE method was concluded to be a fast and robust method that should be applicable for the rapid scanning of any mutation in an exonic sequence.

Mutation detection based on chemical mismatch cleavage (CMC) is relatively new (19), with the underlying principle being chemical modification and cleavage at the site of mismatched $\mathrm{C}$ or $\mathrm{T}$ in heteroduplexes-hydroxylamine $\left(\mathrm{NH}_{2} \mathrm{OH}\right)$ or osmium tetraoxide $\left(\mathrm{OsO}_{4}\right)$ are used as chemical modifiers, and piperidine is used as the chemical cleavage probe. Recently, Ren et al. (79) combined the CMC approach with CE-LIF for detecting the common T833C and G919A mutations in exon 8 of the cystathionine $\beta$-synthase $(C B S)$ gene. The $5^{\prime}$-fluorescein-labeled single strands of 40 and 61 nucleotides, resulting from CMC at T833C and G919A sites on the 186-bp fragment encompassing exon 8 , were analyzed under denaturing conditions with short-chain linear polyacrylamide and detected with sheath-flow LIF. The CMC approach is advantageous in that it not only detects new mutations but also indicates their locations. However, the use of hazardous reagents will likely limit its application.

A novel mutation detection strategy named the mismatch identification DNA analysis system (MIDAS) was recently reported (5). The significant difference between this and other mutation detection approaches is that this method avoids PCR, which some consider to be error prone with respect to the Taq DNA polymerase incorporation of the correct bases into PCR products. MIDAS utilizes $32 \mathrm{P}$ - or FITC-labeled oligonucleotides 20-50 nucleotides long as mutation probes that hybridize to the target sequence to form a heteroduplex molecule at the reaction temperature. A mismatch repair enzyme then cuts the 


\section{Molecular Diagnostic Techniques}

probe at the point of mismatch, which makes the cleaved probe thermally unstable - this leads to dissociation from the target. This oscillating process amplifies the cleaved probe. Following termination of the reaction, the full-length and cleaved DNA fragments are separated by slab-gel or CE. MIDAS was demonstrated to be able to differentiate between a $B R C A 1$ wild-type sequence and a $B R C A 1185 \mathrm{del} A \mathrm{G}$ mutation. It is concluded that MIDAS with CE-LIF should make detection of known point mutations, deletions, and insertions a rapid, cost-effective, and automated approach. Finally, triplet repeat expansions, which have been associated with 12 hereditary neurodegenerative disorders such as X-linked spinal and bulbar muscular atrophy and Huntington's disease (89), have not been seen investigated by CE approach so far.

\section{Molecular Analysis in Forensics}

Gonen et al. (26) showed that CESSCP could also be used for forensic analysis purposes, genotyping SNPs in a large sample population for the purpose of developing dense genetic maps. Other typical mutation and polymorphism analyses also can be performed using CE, including RFLP, variable number of tandem repeat (VNTR), microsatellite analysis, and hybridization techniques (4). RFLP analysis by CE uses a restriction enzyme to digest specific DNA sites, followed by CE separation to detect polymorphisms resulting from the loss or creation of a site at which that particular restriction enzyme cuts. Butler et al. (12) developed this method for rapid mitochondrial DNA typing using multiple restriction enzymes. In addition, the presence of a $\mathrm{T} \rightarrow \mathrm{C}$ transition at position 16189 could be predicted from the presence of nonspecific PCR products in the CE results.

VNTR analysis is a method to detect polymorphic tandem repeats in the human genome, which contains large numbers of repetitive DNA sequences with repeat units that range from 8 to $50 \mathrm{bp}$ in length. Each person has, at most, two different alleles of any given repeat sequence, one from each chromosome, and the variable numbers of repeat units constitute a fragment length polymorphism (4) that can be analyzed by electrophoresis. Nishimura et al. (70) developed CE-LIF VNTR analysis of the human genome D1S80 locus for individual identification purpose. The D1S80 locus, located on chromosome 1 and containing a 16-bp repeat, generally contain $14-41$ repeats of the basic unit; thus, alleles range from 369 to 801 bp in size. A D1S80 ladder, containing a copy of each num ber of repeats, with a 150-bp internal standard fragment was used to compare PCR-amplified DNA fragments from an individual to which the same 150-bp standard had been added. The individual was identified as possessing alleles with 18 and 31 repeat units. Zhang and Yeung (108) also investigated CE-LIF for genetic typing of VNTR polymorphisms in the human D1S80 locus. Coinjection of the D1S80 ladder with PCR-amplified DNA products eliminated errors caused by variations during injection and separation and allows for the determination of allele fragment sizes with high accuracy, resolution, and speed. This established CE-LIF as a powerful technique for determining the number of repeat units in PCR-amplified VNTR alleles for rapid individual identification in forensic medicine.

Microsatellites or STRs are genetically similar to VNTR at the molecular level, with the distinction that the core repeat unit of microsatellites range from two to six bases. Both VNTR and microsatellites show some degree of heterogeneity in the core repeat unit [e.g., base substitutions, insertions, or deletions (4)] requiring highly accurate electrophoretic analysis. Sumita et al. (92) established a CE method for analyzing the intron 13 microsatellite repeat polymorphism (MRP) in the factor VIII gene for diagnosis of hemophilia A. CE resolved the PCR products from the intron 13 MRP, even with repeat numbers of 20 and 21, which differs by only $2 \mathrm{bp}$. Shen et al. (85) developed a CE method with a non-gel sieving matrix to separate 10 STR alleles of the $P A H$ gene in the Chinese population. All 10 alleles of a tetrameric STR in $P A H$ genes could be well separated, with more accurate and reliable results compared to PAGE. Lazaruk et al. (57) demonstrated that $\mathrm{CE}$ provided an automated and precise method for genotyping using the STR system. Simulta- neous analysis of 10 fluorescently labeled STR loci from a single PCR am plification kit $\left(\mathrm{Amp} F / \mathrm{STR}\right.$ Profiler ${ }^{\mathrm{TM}}$ kit; Applied Biosystems) provides the power to discriminate approximately one individual in five billion using a single PCR amplification. The separation of STR loci with single-nucleotide resolution was achievable. Kleparnik et al. (51) used CE-LIF to investigate the repeat polymorphism of a $(\mathrm{CA})_{18} \mathrm{mi}-$ crosatellite repeat in intron 5 of the gene for FcERI $\beta$, a high-affinity glycoprotein receptor for $\mathrm{IgE}$ located on chromosome 11 (11q13). The PCR products, ranging from 116 to $210 \mathrm{bp}$, were analyzed in $3 \mathrm{~min}$ using a $6-\mathrm{cm}$ effective length capillary. Resolution of $4 \mathrm{bp}$ was achieved with the analysis time reduced by a factor of 100 when compared to slab-gel electrophoresis.

\section{MICROCHIP ELECTROPHORE- SIS AS AN EMERGING DIAG- NOSTIC PLATFORM}

Microchip electrophoresis platforms emerged when the effort towards miniaturization of capillary electrophoresis was achieved in 1992 by Manz et al. (64). Although the principle of the electrophoresis assay remains unchanged, the microchip system is drastically different from its parental capillary system. On the microchip platform, the separation channels and the sample injection channels, as well as sample preparation and/or pre- or post-column reactors, can all be microfabricated on a planar substrate sealed with a cover plate; therefore, manipulation of multiple functions could be achieved on a single platform. The classic design of a single-channel microchip involves a short (injection) channel that intersects a longer (separation) channel-a reservoir is found at the ends of each of these as shown in Figure 3. Also shown in this figure is the setup for LIF detection on a single-channel microchip. To perform a separation, an injection voltage of several hundred volts is first applied across the sample and sample waste reservoirs to migrate the sample to the injection cross, which typically represents an injection volume of 50-100 pL. A separation voltage of $1000-4000 \mathrm{~V}$ is then applied to the separation channel, 
which induces separation of the analyte zones before they reach the detection window several centimeters downstream from the injection cross. Although sample injection is around 50 $\mathrm{pL}$, the actual sample volume loaded is $2-4 \mu \mathrm{L}$ depending on the reservoir size. Typical microchip separation times are around $120 \mathrm{~s}$. In the past decade, mi- crochip electrophoresis has undergone substantial development as a result of the research efforts by the Manz, Harrison, Ramsey, and Mathies groups. Integrated microchip designs, advanced detection systems, and new applications are all being investigated in research laboratories around the world. Application areas demonstrated as suitable for

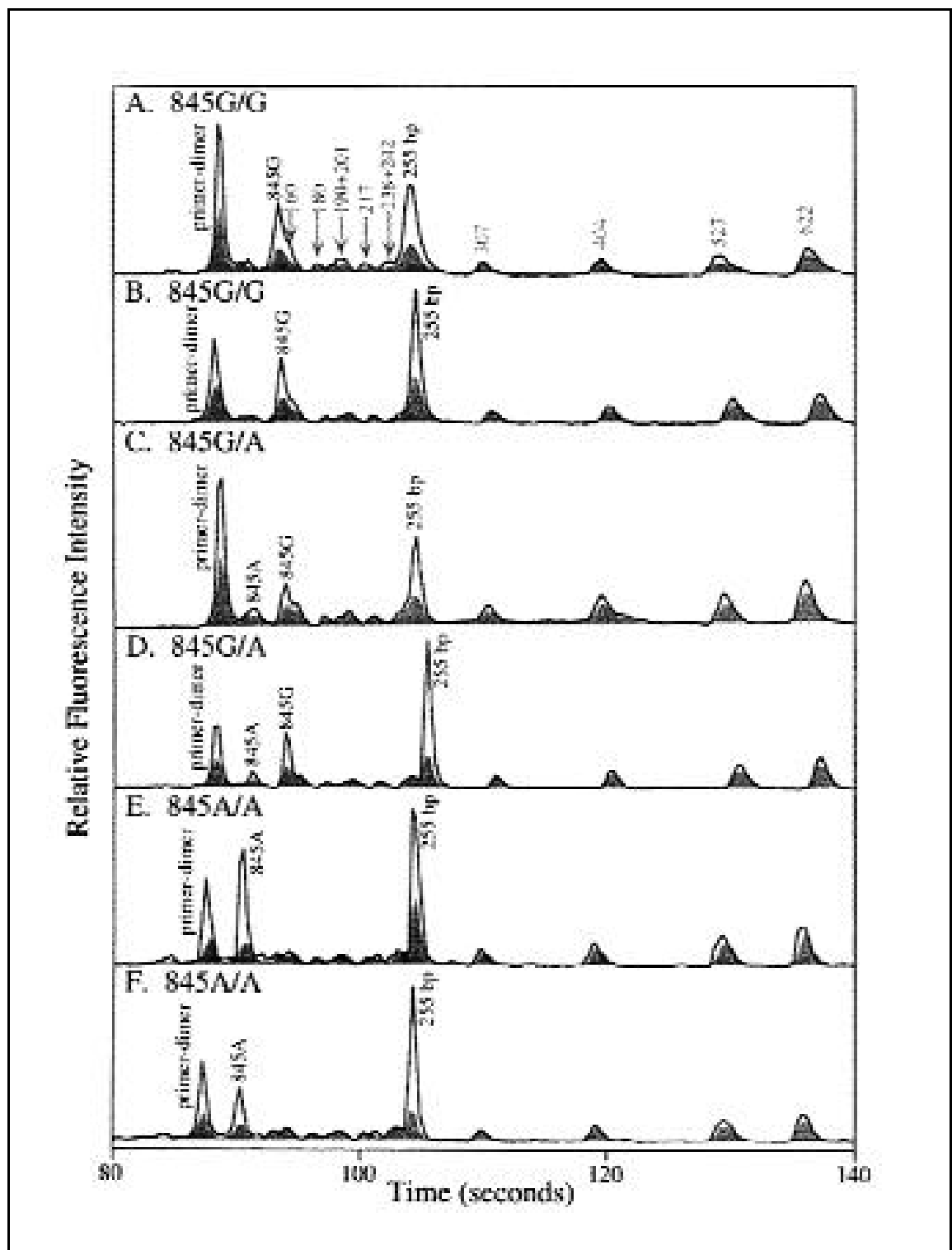

Figure 5. Electropherograms of six HLA-H samples genotyped using a 12-channel CAE chip with two-color fluorescent labeling and detection. The restriction assay for HLA-H genotyping detects an $R s a$ r restriction site created by a $\mathrm{G} \rightarrow \mathrm{A}$ transition at nucleotide 845 in the coding sequence of the HLA-H gene. The normal (845G) type exhibits two fragments of approximately 255 and $145 \mathrm{bp}$, the variant (845A) type has approximately $255 \mathrm{bp}$ fragment and two others at approximately 115 and $30 \mathrm{bp}$, the heterozygote type (845G/A) exhibits the four-fragment composite pattern. The samples in panels A and B were typed as $845 \mathrm{G} / \mathrm{G}$, in panels $\mathrm{C}$ and $\mathrm{D}$ as $845 \mathrm{G} / \mathrm{A}$, and in panels $\mathrm{E}$ and $\mathrm{F}$ as $845 \mathrm{~A} / \mathrm{A}$. The signal in the green channel $(510-540 \mathrm{~nm})$ is indicated by the line, and the signal in the red channel $(>645 \mathrm{~nm})$ is indicated by the gray region. The pBR322 MspI ( $2 \mathrm{ng} / \mu \mathrm{L})$ was prelabeled with butyl TOTIN (1 dye:25 bp), and the HLA-H DNA (1:6 dilution) was labeled on-column with $0.2 \mu \mathrm{M}$ thiazole orange in the running buffer. 


\section{Molecular Diagnostic Techniques}

$\mathrm{CE}$ are rapidly being extended onto microchip platforms. In the clinical diagnostic area, protein and DNA analysis on microchips are of particular interest.

Protein analysis constitutes an area of tremendous interest that is waiting to be fully addressed by microchip electrophoresis. The successful implementation of UV absorbance detection in microchip systems is hampered by path length issues that severely limit sensitive detection. While extraordinary approaches have yielded success, this is not likely to become popular until some simple and efficient form of light coupling becomes available. Consequently, a number of approaches for detecting proteins have been reported in the literature, all involving fluorescent detection of target proteins. These include serum protein analysis $(17,53,83)$ and fluorescent dye-labeled model protein separations $(61,107)$. Schmalzing et al. (83) demonstrated an immunoassay for $\mathrm{T} 4$ in serum for the clinical evaluation of thyroid function using both normal $\mathrm{CE}$ and fused silica microchips. The immunoassay was performed in a com petitive format in which labeled antigens competed with antigens from the serum for antibody binding sites, with the free labeled antigen used for quantitation. The microchip electrophoretic separation of free from bound-labeled T4 was complete in $15 \mathrm{~s}$ on microchips, while normal CE separation required 1 min. Koutny et al. (53), from the same group, earlier reported a microchip electrophoretic immunoassay for serum cortisol using the same method. The assay determined cortisol in blood serum over the range of clinical interest (1-60 $\mu \mathrm{g} / \mathrm{dL})$ without sample extraction or other preparation steps and the separation complete within $30 \mathrm{~s}$. Colyer et al. (17) have made efforts towards the microchip-based separation and quantification of human serum proteins for clinical diagnosis, but analysis of a true human serum sample was not achieved because of the poor sensitivity of the TNS-labeled serum proteins.

Liu et al. (61) performed microchip separation of model proteins, followed by postcolumn labeling with a fluorogenic dye before laser-induced fluorescence detection. The fluorogenic dye diffused into detection point from a reservoir near the detection window is presumed to bind to hydrophobic domains of native proteins and induce a conformational change that generates strong fluorescent signal. Yao et al. (107) demonstrated microchip-based SDS-CGE separation of proteins precolumn labeled with 5- and 6-carboxyfluorescein succinimidyl ester (fluorescein-NHS) or fluorescein-5-maleimide (fluorescein-MAL) and detected with LIF; the separation of five SDS-protein standards was complete in less than 35 s. As pre- or post-column labeling of protein samples with fluorescent dyes is tedious, very recently, Bousse et al. (11) developed a protocol that incorporates a fluorescent dye into the run buffer system, thereby greatly reducing the com plexity associated with the sample-labeling procedure. One pitfall with this method is that the fluorescent dye coupled with SDS in the system generates large background interference and a dilution step before LIF detection has to be included. The same protocol could deem CE separation and detection problematic. A parallel study by Jin et al. (45) addressed the problem of background interference by using a different fluorogenic dye. The beauty of this protocol is that it could be used with either the capillary or microchip format. It is reasonable to speculate that this new finding could greatly advance our current rate of performing protein analysis.

As a result of the ease and sensitivity of DNA detection using LIF detection, DNA separations on microchips are far more advanced than protein separations. An ever-increasing literature describes the recent progress in this area related to rapid clinical diagnosis of disease based on PCR-amplified DNA $(14,34,47,66$, $68,86,97,106)$. Tian et al. (97) reported SSCP analysis on a single-channel glass microchip coated with polyvinylpyrrolidone (PVP; $\mathrm{M}_{\mathrm{r}}, 360 \mathrm{kDa}$ ) for the detection of common mutations in two breast cancer susceptibility genes, $B R C A l$ and $B R C A 2$, in the Ashkenazi Jewish population. The same procedure used in the capillary (97) was effortlessly translated to the microchip platform. Profiles of the wild-type and mutant alleles, performed in $140 \mathrm{~s}$, are different and easily distinguishable from each other (Figure 4); the wild-type alleles have one or three peaks, while the mutant alleles have three to seven peaks in the range investigated. In this study, the microchip-based SSCP analysis was found to be 4-fold faster than the CE-based assay. Tian et al. (96) also successfully transferred AS-PCR-HDA to microchip format. The electrophoresis time was reduced from 10-25 min to less than 180 s. Höfgartner et al. (34), using a single-channel coated glass microchip, accomplished the detection of herpes sim plex virus (HSV) PCR products from $\mathrm{CSF}$ for the rapid diagnosis of herpes simplex encephalitis (HSE). The microchip-based electrophoresis rapidly and accurately separated HSV PCR products in less than $100 \mathrm{~s}$, as compared to $18 \mathrm{~h}$ for identical results obtained by hybridization, the established clinical PCR product detection method. For analysis of $20 \mathrm{CSF}$ samples, the detection of HSV by microchip electrophoresis in combination with amplification by conventional PCR can be completed within $3 \mathrm{~h}$. Therefore, the total analysis time with microchip electrophoresis is reduced by a factor of approximately 6 when compared to hybridization. In fact, the detection of all viral agents causing encephalitis may be possible in a single microchip analysis.

Munro et al. (68) translated assays for $\mathrm{T}$ - and B-cell lymphoproliferative disorders from a slab-gel to a capillary and further to a microchip. The microchip-based electrophoretic separation effectively resolved PCR-amplified fragments from the variable region of the T-cell receptor- $\gamma$ gene (150-250 bp) and the immunoglobulin heavy chain gene (80-140 bp), yielding diagnostically relevant information regarding the presence of clonal DNA populations. The separation time on microchip devices was dramatically reduced (160 $\mathrm{s}$ vs. $2.5 \mathrm{~h}$ ) with no loss of diagnostic information when compared with current methodologies (SGE).

Shi et al. (86) demonstrated on a 96channel radial capillary array electrophoresis microplate the genotyping of 96 methylenetetrahydrofolate reductase (MTHFR) alleles; this gene encodes a protein that is critical in the regulation of folate and methionine metabolism. A sample throughput of approximately 0.6 samples/s was obtained using this system. Medintz et al. (67) performed high-speed SNP typing of a hereditary haemochromatosis mu- 
tation (S65C) in the HFE gene using the same 96-channel radial capillary array electrophoresis microplates. The S65C mutation, caused by a $193 \mathrm{~A} \rightarrow \mathrm{T}$ substitution, was detected in under 2 min by separating $211 \mathrm{bp}$ of the A-allele-specific PCR product from $201 \mathrm{bp}$ of T-allele-specific product amplified by allele-specific primers covalently labeled with Rox (red) and R110 (blue). Medintz et al. (66) further challenged them selves by performing multiplex SNP analysis of three hemochromatosis-related mutations [i.e., the $\mathrm{C} 282 \mathrm{Y}(845 \mathrm{G}$ $\rightarrow \mathrm{A})$ mutation, the H63D $(187 \mathrm{C} \rightarrow \mathrm{G})$ mutation, and the S65C $(193 \mathrm{~A} \rightarrow \mathrm{T}) \mathrm{mu}-$ tation], two of which are very closely located within the $H F E$ gene (6 bp). It is worth mentioning that simultaneous analysis of three mutation sites is accomplished in this work, which is challenging with current SSCP or HDA because of the complication of electropherograms generated therein. The energy transfer (ET) dye-labeled primers used enhanced the excitation efficiencies of all four labels with a single laser line to obtain higher sensitivity. In addition, denaturing LPA was employed as the separation matrix to achieve 1-bp resolution as compared to hydroxyethylcellulose (HEC), which typically yields approximately 3-bp resolution.

Woolley et al. (106) performed the genotyping of HLA-H, a marker gene for the diagnosis of hereditary hemochromatosis on a 12-channel capillary array electrophoresis chip, with separation and detection of all 12 samples in less than $160 \mathrm{~s}$, which is equivalent to 13 s/sample (Figure 5). Rather than glass microchips, where a coated channel is required to perform DNA separations, single-channel plastic microchip electrophoretic devices were demonstrated by Chen et al. (14) for clinical analysis of PCR products of hepatitis $\mathrm{C}$ virus (HCV). The HCV assay developed on fused silica capillary was transferable to the untreated polymethylmethacrylate microchip with minimum modifications and substantially reduced the analysis time from 15 to $1.5 \mathrm{~min}$.

The typical characteristic with microchip electrophoresis separations is high speed, normally 4- to 10 -fold faster than conventional $\mathrm{CE}$, which was already shown to be much faster than SGE. If parallel processing is per- formed, then the sample analysis throughput is further greatly increased. Other advantages with microchips are simplicity, the capability of integrating multiple functions, and potential automation. The practical application of this technique in the clinical diagnostic laboratory seems promising, and advances are already being reported. It is postulated that the benefits of utilizing this innovative technology in clinical diagnostic laboratory will be fully demonstrated in the years to come.

\section{FUTURE PROSPECTS}

$\mathrm{CE}$ as a clinical diagnostic tool is maturing. As new areas are discovered where CE provides advantages over conventional methodologies, it is expected that more and more assays using $\mathrm{CE}$ are going to be introduced into clinical laboratories. This will renovate current labor-intensive and time-consuming protocols and help to realize fully automated analyses. In parallel with this, clinically oriented instrumentation for microchip-based analysis that will satisfy the special requirements of clinical sector will be further developed.

Rapid clinical diagnosis on microchip platform, however, is still in its infancy. Thus far, the research has focused on investigating simple microchip-based clinical diagnostic assays. These are limited, in part, by the current detection technologies but are not yet suitable for use in the clinical laboratory environment. The microchip pre-separation protocol (e.g., channel flushing and buffer and sample loading) remains problematic with reusable microchips. Typically, the microchip electrophoresis separations only take 100-200 s, while the microchip preparations take much longer, are labor-intensive, and are not yet fully automatable. Clearly, the development of an appropriate macro-to-micro interface is needed, especially if microchip analysis is to be used either repeatedly or in a high-throughput manner. This will likely involve a robotic system through a macro-to-micro interface that is capable of flushing and loading in an automated manner. While a number of industrial efforts focused on highthroughput drug screening are making 
progress in this direction (e.g., Caliper Technologies and Aclara BioSciences, Mountain View, CA, USA), this is a clear opportunity for academically based engineers to work closely with chemists and biologists to develop fully automated and integrated systems for microchip analysis. Additionally, com plete miniaturization of the microfluidic chip system will rely heavily on the development of miniaturized detection systems. At some point, the miniaturized detection system and microchip could be easily integrated to form a portable mini-scale system (101) that will allow physicians to perform clinical diagnostic tests in their office or at a patient's bedside and realize the true "point of care" concept.

\section{REFERENCES}

1.Arakawa, H., S. Nakashiro, M. Maeda, and A.Tsuji. 1996. Analysis of single-strand conformation polymorphisms by capillary electrophoresis. J. Chromatogr. A 722:359-368.

2.Arndt, T., R. Hackler, T.O. Kleine, and A.M. Gressner. 1998. Validation by isoelectric focusing of the anion-exchange isotransferrin fractionation step involved in determination of carbohydrate-deficient transferrin by the CDTect assay. Clin. Chem. 44:27-34.

3.Atha, D.H., H.M. Wenz, H. Morehead, J. Tian, and C.D. O'Connell. 1998. Detection of p53 point mutations by single strand conformation polymorphism: analysis by capillary electrophoresis. Electrophoresis 19:172-179.

4.Baba, Y. 1996. Analysis of disease-causing genes and DNA-based drugs by capillary eelectrophoresis towards DNA diagnosis and gene therapy for human diseases. J. Chromatogr. B 687:271-302.

5.Bazar, L., G.B. Collier, P.G. Vanek, B.A. Siles, Y.W. Kow, P.W. Doetsch, R.P. Cunningham, and J.G. Chirikjian. 1999. Mutation identification DNA analysis system (MIDAS) for detection of known mutation. Electrophoresis 20:1141-1148.

6.Bergert, J.H., R.R. Liedtke, R.P. Oda, J.P. Landers, and D.M. Wilson. 1997. Development of a nonisotopic capillary electrophoresis-based method for measuring glomerular filtration rate. Electrophoresis 18:1827-1835.

7.Bienvenu, J., M.S. Graziani, F. Arpin, H. Bernon, C. Blessum, C. Marchetti, G. Righetti, M. Somenzini et al. 1998. Multicenter evaluation of the Paragon CZE ${ }^{\circledR} 2000$ capillary zone electrophoresis system for serum protein electrophoresis and monoclonal component typing. Clin. Chem. 44:599605 .

8.Bjørheim, J., S. Lystad, A. Lindblom, U. Kressner, S. Westring, S. Wahlberg, G. Lindmark, G. Gaudernack et al. 1998. Mutation analyses of $K R A S$ exon 1 comparing three different techniques: temporal tempera- ture gradient electrophoresis, constant denaturant capillary electrophoresis and allele specific polymerase chain reaction. Mutat. Res. Fund. Mol. Mech. Mut. 403:103-112.

9.Bosserhoff, A.K., S. Seegers, C. Helerbrand, J. Scholmerich and R. Buttner. 1999. Rapid genetic screening for hemochromatosis using automated SSCP-based capillary electrophoresis (SSCP-CE). BioTechniques 26:1106-1110.

10.Bossuyt, X., G. Schiettekatte, A. Bogaerts, and N. Blanckaert. 1998. Serum protein electrophoresis by CZE 2000 clinical capillary electrophoresis system. Clin. Chem. 44:749759.

11.Bousse, L., S. Mouradian, A. Minalla, H. Yee, K. Williams, and R. Dubrow. 2001. Protien sizing on a microchip. Anal. Chem. 73:1207-1212

12.Butler, J.M., M.R. Wilson, and D.J. Reeder. 1998. Rapid mitochondrial DNA typing using restriction enzyme digestion of polymerase chain reaction amplicons followed by capillary electrophoresis separation with laser-induced fluorescence detection. Electrophoresis 19:119-124.

13.Cao, P. and M. Moini. 1999. Separation and detection of alpha- and beta-chains of hemoglobin of a single intact red blood cell using capillary electrophoresis/electrospray ionization time-of-flight mass spectrometry. J. Am. Soc. Mass Spectr. 10:184-186.

14.Chen, Y.H., W.C. Wang, K.C. Young, T.T. Chang, and S.H. Chen. 1999. Plastic microchip electrophoresis for analysis of PCR products of hepatitis $\mathrm{C}$ virus. Clin. Chem. 45:1938-1943.

15.Clark, R., J.A. Katzmann, R.A. Kyle, M. Fleisher, and J.P. Landers. 1998. Differential diagnosis of gammopathies by capillary electrophoresis and immunosubtraction: analysis of serum samples problematic by agarose gel electrophoresis. Electrophoresis 19:2479-2484

16.Conti, M., C. Gelfi, A.B. Bosisio, and P.G. Righetti. 1996. Quantitation of glycated hemoglobins in human adult blood by capillary isoelectric focusing. Electrophoresis 17:15901596.

17.Colyer, C.L., S.D. Mangru, and D.J. Harrison. 1997. Microchip-based capillary electrophoresis of human serum proteins. J. Chromatogr. A 781:271-276.

18. Cotton, F., C.Y. Lin, B. Fontaine, B. Gulbis, J. Janssens, and F. Vertongen. 1999. Evaluation of a capillary electrophoresis method for routine determination of hemoglobins A2 and F. Clin. Chem. 45:237-243.

19.Cotton, R.G.H., N.R. Rodrigues, and R.D. Campbell. 1988. Reactivity of cytosine and thymine in single-base pair mismatches with hydroxylamine and osmium tetroxide and its application to the study of mutations. Proc. Natl. Acad. Sci. USA 88:4397-4401.

20.Doelman, C.J.A., C.W.M. Siebelder, W.A. Nijhof, C.W. Weykamp, J. Janssens, and T.J. Penders. 1997. Capillary electrophoresis system for hemoglobin A (1c) determinations evaluated. Clin. Chem. 43:644-648.

21.Durkin, D.P., K.A. Cole, and C.L. Copper. 1998. Capillary electrophoretic determination of carboxyhemoglobin concentrations in post- mortem blood samples. J. Capillary Electrop. 5:129-132.

22.Ekstrøm, P.O., A.-L. Børresen-Dale, H. Qvist, K.E. Giercksky, and W.G. Thilly. 1999. Detection of low-frequency mutations in exon 8 of the TP53 gene by constant denaturant capillary electrophoresis (CDCE). BioTechniques 27:128-135.

23.Friedberg, M.A. and Z.K. Shihabi. 1997. Urine protein analysis by capillary electrophoresis. Electrophoresis 18:1836-1841.

24.Ghozzi, R., P. Morand, A. Ferroni, J.L. Beretti, E. Bingen, C. Segonds, M.O. Husson, D. Izard et al. 1999. Capillary electrophoresis-single-strand conformation polymorphism analysis for rapid identification of Pseudomonas aeruginosa and other gramnegative nonfermenting bacilli recovered from patients with cystic fibrosis. J. Clin. Microbiol. 37:3374-3379.

25.Giordano, B.C., M. Muza, A. Trout, and J.P. Landers. 2000. Dynamically-coated capillaries allow for capillary electrophoretic resolution of transferrin sialoforms via direct analysis of human serum. J. Chromatogr. B 742:79-89.

26.Gonen, D., J. Veenstra-VanderWeele, Z Yang, B.L. Leventhal, and E.H. Cook. 1999. High throughput fluorescent CE-SSCP SNP genotyping. Mol. Psychiatr. 4:339-343

27.Hempe, J.M. and R.D. Craver. 2000. Separation of hemoglobin variants with similar charge by capillary isoelectric focusing: value of isoelectric point for identification of com mon and uncommon hemoglobin variants. Electrophoresis 21:743-748.

28.Hempe, J.M., J.N. Granger, and R.D. Craver. 1997. Capillary isoelectric focusing of hemoglobin variants in the pediatric clinical laboratory. Electrophoresis 18:1785-1795.

29.Hempe, J.M., J.N. Granger, R.P. Warrier, and R.D. Craver. 1997. Analysis of hemoglobin by capillary isoelectric focusing. J. Capillary Electrop. 4:131-135.

30.Hempel, G. 2000. Strategies to improve the sensitivity in capillary electrophoresis for the analysis of drugs in biological fluids. Electrophoresis 21:691-698.

31.Henskens, Y., J. de Winter, M. Pekelharing, and G. Ponjee. 1998. Detection and identification of monoclonal gammopathies by capillary electrophoresis. Clin. Chem. 44:11841190 .

32.Hiraoka, A., T. Arato, I. Tominaga, and A. Anjyo. 1997. Capillary electrophoretic analyses of beta-trace protein and other low molecular weight proteins in cerebrospinal fluid from patients with central nervous system diseases. J. Pharmaceut. Biomed. 15:1257-1263.

33.Hiraoka, A., T. Arato, I. Tominaga, N. Eguchi, H. Oda, and Y. Urade. 1997. Analysis of low-molecular-mass proteins in cerebrospinal fluid by sodium dodecyl sulfate capillary gel electrophoresis. J. Chromatogr. B 697:141-147.

34.Höfgartner, W.T., A.F.R. Huhmer, J.P. Landers, and J.A. Kant. 1999. Rapid diagnosis of herpes simplex encephalitis using microchip electrophoresis of PCR products. Clin. Chem. 45:2120-2128.

35.Houlihan, C., A. Scott, M. Jenkins, D. Parkin, T. Osicka, and G.A. Jerums. 1999. 
Comparison of the plasma disappearance of iohexol and Tc-99m-DTPA for the measurement of glomerular filtration rate (GFR) in diabetes. Aust. NZ J. Med. 29:693-700.

36.Inazuka, M., H.M. Wenz, M. Sakabe, T. Tahira, and K. Hayashi. 1997. A streamlined mutation detection system: multicolor postPCR fluorescence labeling and single-strand conformational polymorphism analysis by capillary electrophoresis. Genome Res. 7:1094-1103.

37.Jackson, H.A., D.J. Bowen, and M. Worwood. 1997. Rapid genetic screening for haemochromatosis using heteroduplex technology. Br. J. Haematol. 98:856-859.

38.Jellum, E., H. Dollekamp, A. Brunsvig, and R. Gislefoss. 1997. Diagnostic applications of chromatography and capillary electrophoresis. J. Chromatogr. B 689:155-164.

39.Jenkins, M.A. 1997. Clinical application of capillary electrophoresis to unconcentrated human urine proteins. Electrophoresis 18:1842-1846

40.Jenkins, M.A. 1998. Three methods of capillary electrophoresis compared with high-resolution agarose gel electrophoresis for serum protein electrophoresis. J. Chromatogr. B 720:49-58.

41.Jenkins, M.A. and M.D. Guerin. 1996. Capillary electrophoresis as a clinical tool. J. Chromtogr. B 682:23-34.

42.Jenkins, M.A., J. Hendy, and I.L. Smith 1997. Evaluation of hemoglobins A (2) quantitation assay and hemoglobin variant screening by capillary electrophoresis. J. Capillary Electrop. 4:137-143.

43.Jenkins, M.A., C. Houlihan, S. Ratnaike, G. Jerums, and J.D. Parkin. 2000. Measurement of iohexol by capillary electrophoresis: minimizing practical problems encountered. Ann. Clin. Biochem. 37:529-536.

44.Jenkins, M.A. and S. Ratnaike. 1999. Capillary isoelectric focusing of hemoglobin variants in the clinical laboratory. Clin. Chim. Acta 289:121-132.

45.Jin, L.J., B.C. Giordano, and J.P. Landers. 2001. Dynamic labeling during capillary or microchip electrophoresis for laser-induced fluorescence detection of protein-SDS com plexes without pre- or post-column labeling. Anal. Chem. 73:4994-4999.

46.Jolliff, C.R. and C.R. Blessum. 1997. Com parison of serum protein electrophoresis by agarose gel and capillary zone electrophoresis in a clinical setting. Electrophoresis 18:17811784.

47.Jorgenson, J.W. and K.D. Lukacs. 1981. Zone electrophoresis in open tubular glass capillaries. Anal. Chem. 53:1298-1302.

48.Katsuragi, K., K. Kitagishi, W. Chiba, S. Ikeda, and M. Kinoshita. 1996. Fluorescence-based polymerase chain reaction single-strand conformation polymorphisms of p53 by capillary electrophoresis. J. Chromatogr. A 744:311-320.

49. Katzmann, J.A., R. Clark, E. Sanders, J.P. Landers, and R.A. Kyle. 1998. Prospective study of serum protein capillary zone electrophoresis and immunotyping of monoclonal proteins by immunosubtraction. Am. J. Clin. Pathol. 110:503-509.

50.Khrapko, K., H.A. Coller, J.S. Hanekamp, and W.G Thilly. 1998. Identification of point mutations in mixtures by capillary electrophoresis hybridization. Nucleic Acids Res. 26:5738-5740

51.Kleparnik, K., Z. Mala, Z. Havac, M. Blazkova, L. Holla, and P. Bocek. 1998. Fast detection of a (CA) (18) microsatellite repeat in the IgE receptor gene by capillary electrophoresis with laser-induced fluorescence detection. Electrophoresis 19:249-255.

52.Kobold, U., J.O. Jeppsson, T. Dulffer, A. Finke, W. Hoelzel, and K. Miedema. 1997. Candidate reference methods for hemoglobin A (1c) based on peptide mapping. Clin. Chem. 43:1944-1951.

53.Koutny, L.B., D. Schmalzing, T.A. Taylor, and M. Fuchs. 1996. Microchip electrophoretic immunoassay for serum cortisol. Anal. Chem. 68:18-22.

54.Kunkel, A. and H. Watzig. 1999. Micellar electrokinetic capillary chromatography as a powerful tool for pharmacological investigations without sample pretreatment: a precise technique providing lost advantages and lim its of detection to the low nanomolar range. Electrophoresis 20:2379-2389.

55.Landers, J.P. (Ed.) 1997. Handbook of Capillary Electrophoresis. CRC Press, Boca Raton, FL.

56.Larsen, L.A., M. Christiansen, J. Vuust, and P.S. Andersen. 1999. High-throughput single-strand conformation polymorphism analysis by automated capillary electrophoresis: robust multiplex analysis and patternbased identification of allelic variants. Hum. Mutat. 13:318-327.

57.Lazaruk, K., P.S. Walsh, F. Oaks, D. Gilbert, B.B. Rosenblum, S. Menchen, D. Scheibler, H.M. Wenz et al. 1998. Genotyping of forensic short tandem repeat (STR) systems based on sizing precision in a capillary electrophoresis instrument. Electrophoresis 19:86-93.

58.Li, M.X., J.T. Wu, L. Liu, and D.M. Lubman. 1997. The use of on-line capillary electrophoresis electrospray ionization with detection via an ion trap storage/reflectron time-of-flight mass spectrometer for rapid mutation-site analysis of hemoglobin variants. Rapid Commun. Mass Sp. 11:99-108.

59.Li, S.F.Y. 1992. Capillary Electrophoresis: Principles, Practice and Applications. Journal of Chromatography Library, Vol. 52, Elsevier Science Publishers B.V., Amsterdam.

60.Litwin, C.M., S.K. Anderson, G. Philipps, T.B. Martins, T.D. Jaskowski, and H.R. Hill. 1999. Comparison of capillary zone and immunosubtraction with agarose gel and im munofixation electrophoresis for detecting and identifying monoclonal gammopathies. Am. J. Clin. Pathol. 112:411-417.

61.Liu, Y.J., R.S. Foote, S.C. Jabobson, R.S. Ramsey, and J.M. Ramsey. 2000. Electrophoretic separation of proteins on a microchip with noncovalent postcolumn labeling. Anal. Chem. 72:4606-4613.

62.Liu, M.S., S. Rampal, D. Hsiang, and F.T.A. Chen. 2000. Automated DNA mutation analysis by single-strand conformation polymorphism using capillary electrophoresis with laser-induced fluorescence detection. Mol. Biotechnol. 15:21-27.
63.Manabe, T., H. Miyamoto, K. Inoue, M. Nakatsu, and M. Arai. 1999. Separation of human cerebrospinal fluid proteins by capillary isoelectric focusing in the absence of denaturing agents. Electrophoresis 20:36773683.

64.Manz, A., D.J. Harrison, E.M.J. Verpoorte, J.C. Fettinger, A. Paulus, H. Ludi, and H.M. Widmer. 1992. Planar chips technology for miniaturization and integration of separation techniques into monitoring systemscapillary electrophoresis on a chip. J. Chromatogr. 593:253-258.

65.Medintz, I.L., C.C.R. Lee, W.W. Wong, K. Pirkola, D. Sidransdy, and R.A. Mathies. 2000. Loss of heterozygosity assay for molecular detection of cancer using energy-transfer primers and capillary array electrophoresis. Genome Res. 10:1211-1218.

66.Medintz, I., W.W. Wong, L. Berti, L. Shiow, J. Tom, J. Scherer, G. Sensabaugh, and R.A. Mathies. 2001. High performance multiplex SNP analysis of three hemochromatosis-related mutations with capillary array electrophoresis microplates. Genome Res. $11: 413-421$.

67.Medintz, I., W.W. Wong, G. Sensabaugh, and R.A. Mathies. 2000. High speed single nucleotide polymorphism typing of a hereditary haemochromatosis mutation with capillary array electrophoresis microplates. Electrophoresis 21:2352-2358.

68.Munro, N., K. Snow, J.A. Kant, and J.P. Landers. 1999. Molecular diagnostics on microfabricated electrophoretic devices: from slab gel- to capillary- to microchip-based assays for T- and B-cell lymphoproliferative disorders. Clin. Chem. 45:1906-1917.

69.Nishimura, A. and M. Tsuhako. 2000. Single strand conformation analysis of Ras oncogene by capillary electrophoresis with laserinduced fluorescence detector. Chem. Pharm. Bull. 48:774-778.

70.Nishimura, A., M. Tsuhako, and Y. Baba. 1998. Analysis of variable number of tandem repeats of human genome D1S80 locus using capillary electrophoresis with laser-induced fluorescence detector. Chem. Pharm. Bull. 46:1639-1642.

71.Oda, R.P., R. Prasad, R.L. Stout, D. Coffin, W.P. Patton, D.L. Kraft, J.F. Obrien, and J.P. Landers. 1997. Capillary electrophoresis-based separation of transferrin sialoforms in patients with carbohydrate-deficient glycoprotein syndrome. Electrophoresis 18:18191826.

72.Olgemoller, J., G. Hempel, J. Boos, and G. Blaschke. 1999. Determination of (E)-5-(2bromovinyl)-2'-deoxyuridine in plasma and urine by capillary electrophoresis. J. Chromatogr. B 726:261-268.

73.Pancholi, P., R.P. Oda, P.S. Mitchell, J.P. Landers, and D.H. Persing. 1997. Diagnostic detection of herpes simplex and hepatitis $C$ viral amplicons by capillary electrophoresis: comparison with Southern blot detection. Mol. Diagn. 2:27-37.

74.Petrini, C., M.G. Alessio, L. Scapellato, S. Brambilla, and C. Franzini. 1999. Serum proteins by capillary zone electrophoresis: approaches to the definition of reference values. Clin. Chem. Lab. Med. 37:975-980. 
75.Prasad, R., R.L. Stout, D. Coffin, and J. Smith. 1997. Analysis of carbohydrate-deficient transferrin by capillary zone electrophoresis. Electrophoresis 18:1814-1818.

76.Prochazkova, A., M. Chouki, R. Theurillat, and W. Thormann. 2000. Therapeutic drug monitoring of albendazole: determination of albendazole, albendazole sulfoxide, and albendazole sulfone in human plasma using nonaqueous capillary electrophoresis. Electrophoresis 21:729-736.

77.Ren, J.C. 2000. High-throughput singlestrand conformation polymorphism analysis by capillary electrophoresis. J. Chromatogr. B 741:115-128.

78.Ren, J.C. and P.M. Ueland. 1999. Temperature and $\mathrm{pH}$ effects on single-strand conformation polymorphism analysis by capillary electrophoresis. Hum. Mutat. 13:458-463.

79.Ren, J., A. Ulvik, H. Refsum, and P.M. Ueland. 1998. Chemical mismatch cleavage combined with capillary electrophoresis: detection of mutations in exon 8 of the cystachionine $\beta$-synthase gene. 44:2108-2114.

80.Rocco, M.V., V.M. Buckalew, L.C. Moore, and Z.K. Shihabi. 1996. Capillary electrophoresis for the determination of glomerular filtration rate using nonradioactive iohexol. Am. J. Kidney Dis. 28:173-177.

81.Sanders, E., J.A. Katzmann, R. Clark, R.P. Oda, Z. Shihabi, and J.P. Landers. 1999 Development of capillary electrophoresis as an alternative to high resolution agarose gel electrophoresis for the diagnosis of multiple sclerosis. Clin. Chem. Lab. Med. 37:37-45.

82.Schlenck, A., B. Herbeth, G. Siest, and S. Visvikis. 1999. Characterization and quantification of serum lipoprotein subfractions by capillary isotachophoresis: relationships with lipid, apolipoprotein, and lipoprotein levels. J. Lipid Res. 40:2125-2133.

83.Schmalzing, D., L.B. Koutny, T.A. Taylor, W. Nashabeh, and M. Fuchs. 1997. Im munoassay for thyroxine (T4) in serum using capillary eletrophoresis and micromachined devices. J. Chromatogr. B 697:175-180

84.Schwartz, H.E. and K.J. Ulfelder. 1992. Capillary electrophoresis with laser-induced fluorescence detection of PCR fragments using thiazole orange. Anal. Chem. 64:17371740.

85.Shen, Y., Q. Xu, F.T. Han, K. Ding, F. Song, Y. Fan, N. Zhu, G.Y. Wu, and B.C. Lin. 1999. Application of capillary nongel sieving electrophoresis for gene analysis. Electrophoresis 20:1822-1828.

86.Shi, Y.N., P.C. Simpson, J.R. Scherer, D. Wexler, C. Skibola, M.T. Smith, and R.A. Mathies. 1999. Radial capillary array electrophoresis microplate and scanner for highperformance nucleic acid analysis. Anal. Chem. 71:5354-5361.

87.Shihabi, Z.K. 2000. Review of applications of capillary electrophoresis for clinical analysis. J. Liq. Chromatogr. RT 23:79-95.

88.Shihabi, Z.K., M.E. Hinsdale, and H.K. Daugherty. 2000. Hemoglobin A (2) quantification by capillary zone electrophoresis. Electrophoresis 21:749-752.

89.Spiegel, R. 1997. Molecular genetics of triplet repeat expansions causing hereditary neurodegenerative disorders. Dev. Brain Dysfunct.
10:293-305.

90.Stead, D.A. 2000. Current methodologies for the analysis of aminoglycosides. J. Chromatogr. B 747:69-93.

91.Stocks, J. and N.E. Miller. 1999. Analysis of apolipoproteins and lipoproteins by capillary electrophoresis. Electrophoresis 20:21182123.

92.Sumita, C., A. Suehiro, A. Sawada, S. Higasa, M. Ueda, and E. Kakishita. 2000. Analysis of intron 13 microsatellite repeat polymorphism of the factor VIII gene by capillary electrophoresis. Semin. Thromb. Hemost. 26:91-96.

93.Tagliaro, F., G. Crivellenye, I. Manetto, Z. Puppi, M. Deyl, and M. Marigo. 1998. Optimized determination of carhohydrate-deficient transferrin isoforms in serum by capillary zone electrophoresis. Electrophoresis 19:3033-3039.

94.Thomas, G.A., D.L. Williams, and S.A. Soper. 2001. Capillary electrophoresis-based heteroduplex analysis with a universal heteroduplex generator for detection of point mutations associated with rifampin resistance in tuberculosis. Clin. Chem. 47:1195-1203.

95. Thormann, W., A.B. Wey, I.S. Lurie, H. Gerber, C. Byland, N. Malik, M. Hochmeister, and C. Gehrig. 1999. Capillary electrophoresis in clinical and forensic analysis: recent advances and breakthrough to routine applications. Electrophoresis 20:3203-3236.

96.Tian, H., L.C. Brody, S. Fan, Z. Huang, and J.P. Landers. 2001. Capillary and microchip electrophoresis for rapid detection of known mutations by combining allele-specific DNA amplification with heteroduplex analysis. Clin. Chem. 47:173-185

97.Tian, H.J., A. Jaquins-Gerstl, N. Munro, M. Trucco, L.C. Brody, and J.P. Landers. 2000. Single-strand conformation polymorphism analysis by capillary and microchip electrophoresis: a fast, simple method for detection of common mutations in BRCA1 and BRCA2. Genomics 63:25-34.

98.Trout, A.L., R. Prasad, D. Coffin, A. DiMartini, T. Lane, C. Blessum, N. Khatter, and J.P. Landers. 2000. Direct capillary electrophoretic detection of carbohydrate-deficient transferrin in neat serum. Electrophoresis 21:2376-2383.

99.Walz, T., J. Geisel, M. Bodis, J.P. Knapp, and W. Herrmann. 2000. Fluorescencebased single-strand conformation polymorphism analysis of mutations by capillary electrophoresis. Electrophoresis 2 1:375-379.

100.Wellel, T., C. Lanvers, S. Fraend, and G. Hempel. 2000. Determination of purines including 2,8-dihydroxyadenine in urine using capillary electrophoresis. J. Chromatogr. A 894:157-164.

101.Wendt, J.R., M.E. Warren, W.C. Sweatt, C.G. Bailey, C.M. Matzke, D.W. Arnold, A.A. Allerman, T.R. Cart et al. 1999. Fabrication of high performance microlenses for an integrated capillary channel electrochromatograph with fluorescence detection. J. Vacuum Sci. Tech. B 17:3252-3255.

102.Wenz, H.M., S. Baumhueter, S. Ramachandra, and M. Worwood. 1999. A rapid automated SSCP multiplex capillary electrophoresis protocol that detects the two common mutations implicated in hereditary hemochromatosis $(\mathrm{HH})$. Hum. Genet. 104:2935 .

103.Wenz, H.M., S. Ramachandra, C.D. O'Connell, and D.H. Atha. 1998. Identification of known p53 point mutations by capillary electrophoresis using unique mobility profiles in a blinded study. Mutat. Res. Genomics 382:121-132

104.Wijnen, P.A.H.M. and M.P. vanDieijen Visser. 1996. Capillary electrophoresis of serum protein-reproducibility, comparison with agarose gel electrophoresis and a review of the literature. Eur. J. Clin. Chem. Clin. Biochem. 34:535-545.

105.Wilson, D.M., J.H. Bergert, T.S. Larson, and R.R. Liedtke. 1997. GFR determined by nonradiolabelled iothalamate using capillary electrophoresis. Am. J. Kidney Dis. 30:646-652.

106.Woolley, A.T., G.F. Sensabaugh, and R.A. Mathies. 1997. High-speed DNA genotyping using microfabricated capillary array electrophoresis chips. Anal. Chem. 69:2181-2186.

107.Yao, S., D.S. Anex, W.B. Caldwell, D.W. Arnold, K.B. Smith, and P.G. Schultz. 1999. SDS capillary gel electrophoresis of proteins in microfabricated channels. Proc. Natl. Acad. Sci. USA 96:5372-5377.

108.Zhang, N.Y. and E.S. Yeung. 1996. Genetic typing by capillary electrophoresis with the allelic ladder as an absolute standard. Anal. Chem. 68:2927-2931.

Address correspondence to:

Dr. Lianji Jin

Department of Chemistry

McCormick Road

University of Virginia

Charlottesville, VA 22901, USA

e-mail:lj4v@virginia.edu

For reprints of this or any other article, contact Reprints@BioTechniques.com 